\title{
Immunotherapy for liver tumors: present status and future prospects
}

\author{
Pablo Matar ${ }^{1,3}$, Laura Alaniz ${ }^{2,3}$, Viviana Rozados ${ }^{1}$, Jorge B Aquino ${ }^{2,3}$, \\ Mariana Malvicini' ${ }^{2}$, Catalina Atorrasagasti², Manuel Gidekel ${ }^{4}$, Marcelo Silva2 \\ O Graciela Scharovsky*1 and Guillermo Mazzolini*2,3
}

\begin{abstract}
Address: ${ }^{1}$ Institute of Experimental Genetics, School of Medical Sciences, National University of Rosario, Santa Fe 3100, (2000) Rosario, Argentina, ${ }^{2}$ Gene Therapy Laboratory, Liver Unit, School of Medicine, Austral University, Av. Presidente Perón 1500, (B1629ODT) Derqui-Pilar, Buenos Aires, Argentina, ${ }^{3}$ CONICET (Consejo Nacional de Investigaciones Científicas y Técnicas), Buenos Aires, Argentina and ${ }^{4}$ VentureL@b, Escuela de Negocios, Universidad Adolfo Ibañez, Av. Diagonal Las Torres 2700, Peñalolen 791000, Santiago, Chile

Email: Pablo Matar - matarpablo@hotmail.com; Laura Alaniz - laualaniz@yahoo.com.ar; Viviana Rozados - viviana.rozados@gmail.com; Jorge B Aquino - aquinojb@yahoo.com; Mariana Malvicini - mariana.malvicini@gmail.com; Catalina Atorrasagasti - mcatalinaa@gmail.com; Manuel Gidekel - mgidekel@gmail.com; Marcelo Silva - msilva@cas.austral.edu.ar; O Graciela Scharovsky* - graciela.scharovsky@gmail.com; Guillermo Mazzolini* - gmazzoli@cas.austral.edu.ar

* Corresponding authors
\end{abstract}

Published: 6 March 2009

Journal of Biomedical Science 2009, 16:30 doi:10.1 I86/1423-0127-16-30

This article is available from: http://www.jbiomedsci.com/content/16/1/30

(c) 2009 Matar et al; licensee BioMed Central Ltd.

This is an Open Access article distributed under the terms of the Creative Commons Attribution License (http://creativecommons.org/licenses/by/2.0), which permits unrestricted use, distribution, and reproduction in any medium, provided the original work is properly cited.
Received: 28 October 2008

Accepted: 6 March 2009

\begin{abstract}
Increasing evidence suggests that immune responses are involved in the control of cancer and that the immune system can be manipulated in different ways to recognize and attack tumors. Progress in immune-based strategies has opened new therapeutic avenues using a number of techniques destined to eliminate malignant cells. In the present review, we overview current knowledge on the importance, successes and difficulties of immunotherapy in liver tumors, including preclinical data available in animal models and information from clinical trials carried out during the lasts years. This review shows that new options for the treatment of advanced liver tumors are urgently needed and that there is a ground for future advances in the field.
\end{abstract}

\section{Background}

Hepatocellular carcinoma (HCC) is the fifth most common cancer and the third leading cause of cancer-related death worldwide [1]. Unfortunately, the incidence and mortality associated with HCC is increasing steadily [2] as a consequence of epidemics of hepatitis $C$ virus (HCV) and hepatitis B virus (HBV). HCV and HBV infections are causally associated with the majority of HCC in the world [3].

Current therapeutic options are extremely disappointing since less than $30 \%$ of the patients evaluated in referral medical institutions can receive a curative therapy, consisting in either resection or transplantation [4]. Thus, in the majority of advanced HCC cases surgery is not possible and the prognosis is dismal due to underlying cirrhosis as well as to poor tumor response to chemotherapeutic agents [4-6].

Unfortunately, advanced colorectal carcinoma (CRC) depict similar scenario [7]. Colorectal carcinoma is one of the most common malignancies and a leading cause of cancer-related death [1]. Hepatic metastases are present in $15-25 \%$ of patients at the time of CRC diagnosis [8]. Surgical resection, which is accepted as first-line 
CRC treatment, cannot be performed in the majority of patients [9]. Following diagnosis, the median survival of untreated patients with liver metastases is 6-12 months [10]. The application of new chemotherapeutic cocktails, including irinotecan or oxaliplatin, result in higher rates of objective responses and survival [11-15] and the recent incorporation of monoclonal antibodies against vascular endothelial growth factor and epidermal growth factor receptors provides additional, although limited, improvement in patients survival $[15,16]$.

Thus, new strategies are needed for treatment of patients with advanced liver tumors and immunotherapy approaches might play a significant role among them. Cancer immunotherapy can be defined as a set of techniques aimed to eliminate malignant tumors through mechanisms involving immune system responses $[17,18]$. The goal of cancer immunotherapy is to understand how to direct against tumors similar kind of extremely potent immune responses such as those naturally occurring against microbial antigens, and subsequently how to apply these results to human cancer diseases. It has been observed in patients with HCC that the presence of a lymphocyte infiltrate is associated with a better prognosis after resection and transplantation [19]. Similarly, presence of lymphocyte infiltration in tumors was correlated with patient survival in CRC: survival rate of patients with large numbers of CD3+-T cells was 5-years higher [20,21].

There is a limited clinical experience regarding the application of immunotherapy in liver tumors contrary to more immunogenic tumors such as melanoma, lymphoma or renal cell carcinoma. Increasing evidence suggests that immune responses are involved in the control of cancer and that the immune system can be manipulated in different ways to recognize and attack tumors (Fig. 1). Unfortunately, the presence of chronic HCV or HBV infection complicates the success of immunotherapy in patients with HCC because these viruses were found to be able to modulate the immune response against tumors and to counteract the immune system of the host [22-24].

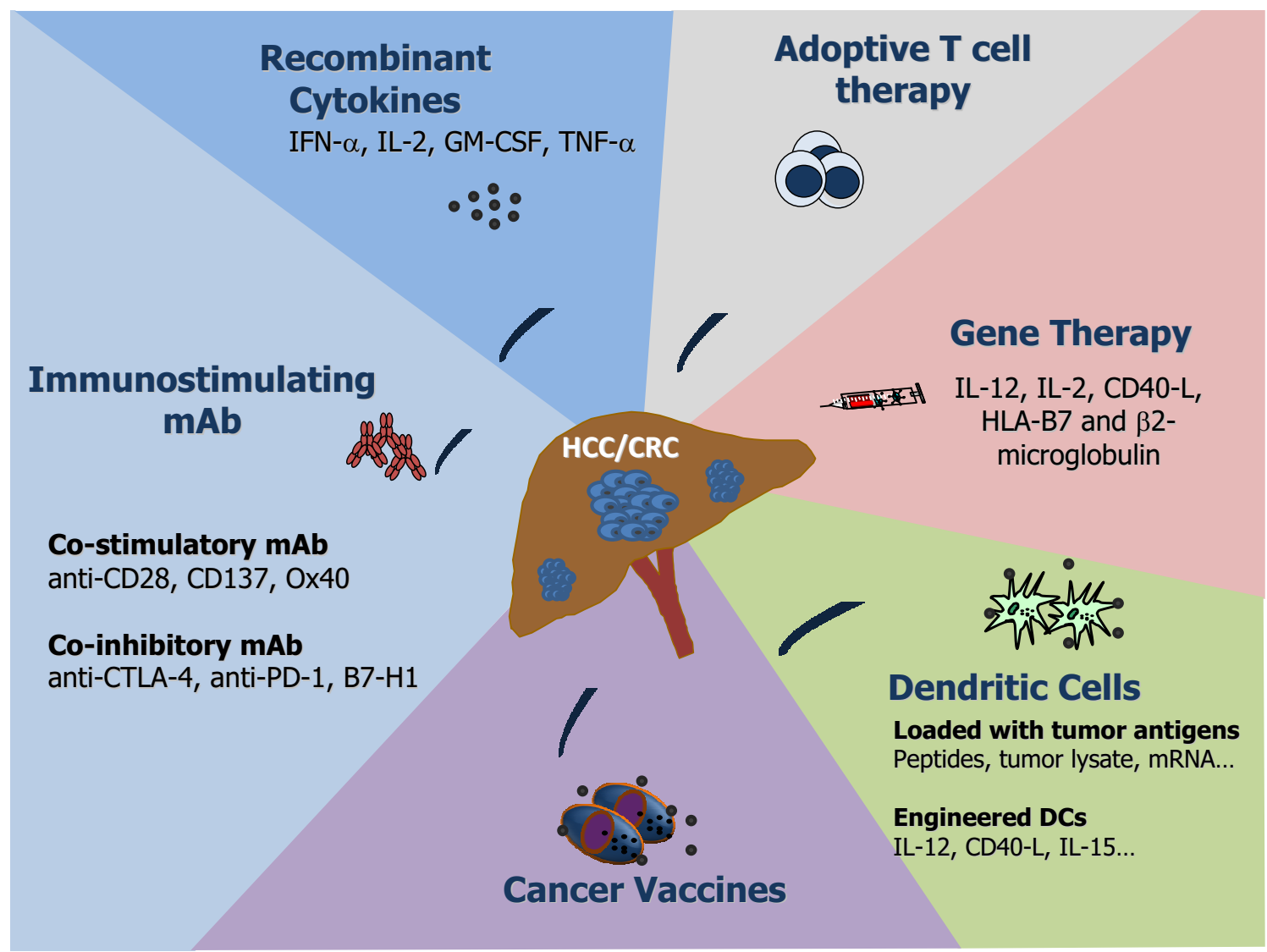

Figure I

Immunotherapeutic strategies for liver tumors: administration of recombinant cytokines, adoptive transfer of tumor-reactive $\mathbf{T}$ cells generated in vitro, gene therapy with cytokines and costimulatory molecules, immunotherapy with dendritic cells, stimulation with immunogenic vaccines or antibodies. 


\section{The immune system and the induction of antitumor immunity - basic concepts}

The immune system is clearly capable of recognizing and eliminating tumor cells, although cancer cells are considered as poorly immunogenic [25]. Compelling evidence suggests that immune cells can eventually play a crucial role in the control of cancer. First, both occasional spontaneous tumor regressions have been described in immunocompetent hosts while increased cancer incidence has been reported in immunocompromised individuals [26]. Second, tumor immunity was demonstrated experimentally in several animal models [27]. Third, the immune system often recognizes the presence of tumors, as reflected by an accumulation of immune cells at tumor sites [28].

Despite the ability of the immune system to react against cancer cells, the presence of a tumor indicates that the developing cancer can avoid detection or to escape the immune response [29]. Mechanisms used to elude recognition include tumor-induced impairment of antigen presentation, activation of negative co-stimulatory signals, and production of immunosuppressive factors [30]. In addition, cancer cells may promote the expansion and/or recruitment of regulatory cells that may contribute to the immunosuppressive network; these populations include regulatory T cells (Treg), myeloid suppressor cells, and distinct subsets of immature and mature regulatory dendritic cells [31].

All of the previously mentioned mechanisms were shown to be induced in the liver by hepatitis viruses [32,33] and a concomitant chronic HCV/HBV infection in HCC patients would probably make the scenario for immunotherapeutic approaches more complicated.

\section{The immunosurveillance and the immunoediting hypothesis}

In the last 30 years we have witnessed a dramatic change in basic concepts related to tumor immunology, from the strict theory of tumor immunosurveillance postulated by Burnet and Thomas $[34,35]$ to the very recent immunoediting concept developed by Schreiber and colleagues [36]. Using a broader look at tumor immunology, these authors have elegantly described tumor progression as a process following three phases: elimination; equilibrium and, finally, escape, in which tumor cells develop several strategies to avoid their immune-mediated elimination. The variety of processes by which tumors evade the immune response is surprisingly large. Even though cancer cells express new or inappropriate antigens, tumors of diverse origin develop common and/or unique mechanisms that enable them to escape from the immune system.

\section{The liver: an immunological privileged organ}

Mechanisms of tolerance and their implications in cancer are of central interest in immunology. The liver is an espe- cial organ for its immunological privileged status which is a consequence of several unique immunological properties causing antigen tolerance rather than immunity $[37,38]$ and relative resistance against liver allograft rejection [39], allowing that $20 \%$ of allotransplanted patients could be withdrawn from long-term immunosuppression [40]. Aggressive autoimmune hepatitis is a somewhat uncommon clinical manifestation of systemic autoimmune disease [41]. Moreover, it has been observed in animal models that naïve liver reactive $T$ cells ignore antigens derived from or expressed in the liver [42], generating tolerance to them [37]. It is important to note that effector Tcells alone may not be sufficient for disease induction without additional inflammatory and costimulatory signals. A potential role for TLR3 has been reported as one of the critical mechanisms of hepatic immune privilege [43].

As it was excellently reviewed by Abe and Thomson [38], liver immunoprivilege properties are likely due to its unique repertoire of antigen-presenting cell (APC) populations, consisting of Kupffer cells (KCs), liver sinusoidal endothelial cells (LSECs) and dendritic cells (DCs). KCs represent $80-90 \%$ of liver resident macrophages and are very efficient in clearing LPS from gut-derived blood circulation but less efficient in activating CD4+ cells. LSECs were shown to efficiently separate leukocytes from hepatocytes [44], are able to express factors involved in T cell death, induce differentiation of CD4+ towards the Th2 anti-inflammatory phenotype and were found to co-stimulate Tregs and inhibit allogeneic T cells. DCs are located in portal areas or circulate through liver sinusoids towards lymph draining vessels, and upon maturation increase their expression levels of IL-12 and CCR7, two molecules involved in CD4+ T cell differentiation towards the Th1 pro-inflammatory phenotype and in DC trafficking towards secondary lymphoid organs, respectively. From all liver APCs, DCs are the most potent to elicit immune responses. Due to the fact that KCs and LSECs constitutively express IL-10 and TGF-beta anti-inflammatory cytokines, T cell differentiation is affected and APC maturation inhibited in the liver $[45,46]$. As a consequence, the DCs are less immunostimulatory than in spleen $[47,48]$.

In addition, hepatic stellate cells (also known as Ito cells) were shown to be involved in liver immunological processes only in case of chronic liver injury. They are induced to transdifferentiate into myofibroblasts and to secrete a number of cytokines and chemokines, such as transforming growth factor beta (TGF-beta) $[49,50]$. In fact, activated hepatic stellate cells have been shown to closely interact with lymphocytes [51] and to have potent antigen-presenting properties [52]. Furthermore, stellate cells from hepatitis patients have been shown to get further activated by lymphocyte proximity, especially by CD8+ cells, and to phagocyte CD45+ cells [53]. Those facts suggest that stellate cells are likely implicated in the down- 
regulation of the immune response in $\mathrm{HCV} / \mathrm{HBV}$-derived cirrhosis and might also be involved in HCC. These findings open new therapeutic opportunities aimed to specifically targeting hepatic stellate cells in advanced cirrhosis and HCC.

Finally, when HCC coexists with HBV/HCV derived cirrhosis, these viruses as shown in chronic hepatitis, would likely exert direct and indirect effects on further downregulation of the immune response through complex and not fully understood mechanisms. They might influence the activity of hepatic stellate cells as well as that of resident and recruited immune cells, such us DCs, through direct viral protein interaction [54-57]. As reviewed by Liu et al. [33] in chronic B/C-viral hepatitis a reduction in the myeloid and plasmacytoid DC liver populations, down-regulation in IL-12 and IFN-gamma levels, an up-regulation of IL-10 and an impairment in DCs capacity to prime naïve T cells may account for the insufficient immune response observed. Similarly, a reduction in circulating DC numbers was found in the peripheral blood of patients with either chronic-B-hepatitis [58] or chronic-C-hepatitis $[59,60]$. HBV/HCV viruses would likely contribute to the DC impaired allostimulatory and IL-12 production capacities observed in HCC patients [61], although this remains to be elucidated.

\section{Hepatic tumors escape from the immune response}

Hepatic tumors use two main strategies to escape from the immune response - attack and defense - the first is designed to attack the immune cells, hence avoiding their antitumor action and the other to defend tumor cells by enabling them to pass unnoticed by the immune response (Table 1).

\section{Attack strategies}

Fas ligand (FasL), a type II transmembrane protein reported to induce apoptosis of Fas-bearing cells [62] was shown to confer immunological privilege to certain tis- sues and organs such as eye, placenta and central nervous system [63-65]. More recently, the interaction of FasL or its secreted isoform (sFASL) produced by tumor cells, with their specific Fas receptor, expressed on T lymphocytes, was implicated in tumor cell evasion from immune surveillance [66]. The $\alpha$-fetoprotein (AFP), an oncofetal protein overexpressed in some HCC, was shown to induce Fas-L and tumor necrosis factor [TNF]-related apoptosis expression in HCC Bel7402 cells, as well as TRAIL receptor and Fas in lymphocytes $[67,68]$. Another pathway developed to attack immune cells involves the interaction of PD-1 (programmed death-1) with its ligands PD-L1 and PD-L2. Immunotherapy with an expression plasmid encoding the extracellular domain of PD-1 (sPD-1) in H22 HCC cells was shown to improve the immune response against tumors [69]. One further mechanism might implicate Galectin-1 (Gal-1) - a $\beta$-galactoside binding protein with immunoregulatory properties, which is known to play a role in cytotoxic immune cells elimination. It is likely that Gal-1 contributes to tumor immune escape by killing activated $T$ cells $[70,71]$. In fact, the expression of Gal-1 was shown to be induced in primary HLF, HuH7 and HepG2 cells [72].

\section{Defense strategies}

The pressure that the immune system exerts on the growth of tumor cells seems to have led them to develop several protection mechanisms against any immune attack. It has been shown that human HCC-related factors not only induce and expand the regulatory CD4+CD25+ T cell population (Tregs), but also enhance their suppressor ability [73]. A high prevalence of Tregs infiltrating HCC seems to be an unfavorable prognostic indicator [74]. Another mechanism frequently used by tumors is the down-regulation of MHC-I [75], B7-1/B7-2 co-stimulatory molecules [76] or transporter associated with antigen processing (TAP)1/2 molecules in human HCC [77]. In addition, HCC cells might escape from CTL-induced apoptosis by increasing $\mathrm{Bcl}-2$ and decreasing $\mathrm{Bcl}-\mathrm{xs}$

Table I: Mechanisms of hepatic tumor-immune escape.

\begin{tabular}{ccccc}
\hline & Attack & & & Defense \\
\hline System & Mechanism & Ref. & System & Mechanism \\
\hline Fas/FasL & T-cell apoptosis & 66 & Tregs & Immunosuppression \\
\hline PD-I/PD-IL & T-cell apoptosis & 69 & MHC-I & Antigen presentation \\
\hline Galectin-I & T-cell apoptosis & 72 & B7-I/B7-2 & Antigen presentation \\
\cline { 2 - 4 } & & & IDO & Immunosuppression \\
\hline
\end{tabular}

Two main strategies to escape from the immune response attack and defense have been demonstrated for HCC in experimental and/or clinical setting. Fas: CD95; FasL: CD95L; PD-I: programmed death-I; PD-IL: programmed death-I ligand; Tregs: Regulatory T cells; IDO: Indoleamine 2,3 dioxygenase. 
expression [78] and/or raising the Survivin level, an important member of the inhibitor of apoptosis (IAP) family $[79,80]$.

Indoleamine 2,3 dioxygenase (IDO) catalyses the degradation of the essential amino acid tryptophan and synthesizes immunosuppressive metabolites [81]. Larrea and colleagues [82] reported that IDO constitutes an important mediator of peripheral immune tolerance in chronic hepatitis $\mathrm{C}$ virus (HCV) infection. Induction of IDO expression may reduce $\mathrm{T}$-cell reactivity to viral antigens in chronic HCV infection and may also influence the immune response against HCC in patients chronically infected with HCV. Understanding of the immune-escape mechanisms should help us to design immunotherapy protocols to increase the efficacy of therapeutic success.

\section{Systemic use of immunostimulatory cytokines}

There is a broad experience regarding the use of cytokines to induce immune and inflammatory responses against cancer $[83,84]$. Cytokines have been shown to act through different mechanisms: i) stimulation of antitumor immune responses; ii) induction of tumor cell apoptosis (e.g. through induction of TRAIL) [85]; iii) interference in uncontrolled proliferation of cancer cells, and iv) antiangiogenesis.

One of the most explored cytokines is interferon alpha (IFN- $\alpha$ ) [86,87]. The IFN- $\alpha$ antitumor mechanism of action includes direct effect on tumor cells, induction of lymphocyte and macrophage cytotoxic activities and antiangiogenesis [88,89]. Two controlled trials comparing IFN- $\alpha$ with symptomatic treatment in patients with HCC were reported. In one of them the use of high doses of IFN- $\alpha(50 \mathrm{MU} / \mathrm{m} 2$, tiw) resulted in a response rate of $36 \%$ [90]. In the other trial, in which lower doses of IFN- $\alpha$ (3 $\mathrm{MU} / \mathrm{m} 2$, tiw) were administered, the response rate was poor (7\%) [91]. Even though it is clear that the different responses are related to the administered doses, the toxicity associated with the higher IFN- $\alpha$ dose is not acceptable, especially for patients with end-stage liver disease. Nevertheless, systemic administration of IFN- $\alpha$ [92] or IFN- $\beta$ [93] should be considered as a supportive treatment after hepatectomy or tumor ablation, which may prevent or delay tumor relapses in patients with HCC [94]. A combination of IFN- $\alpha$ and chemotherapy was applied to patients for treatment of advanced HCC $[95,96]$ and metastatic CRC to the liver [97]; however, randomized controlled studies failed to demonstrate that combination protocol results in improved outcome when compared to chemotherapy treatment alone [98,99].

Interleukin-2, an immunostimulatory cytokine, has been administered alone or in combination with other treatments against liver tumors. The non-controlled nature of most studies precludes from any definitive conclusion. Systemic IL-2 was able to produce objective responses against HCC when given alone [100] or in combination with melatonin [101] or lymphokine activated killer (LAK) cells [102]. On the other hand, hepatic artery infusion of interleukin 2, with or without chemotherapy, induced objective remissions in 5\% to $15 \%$ of liver metastases from CRC $[95,103,104]$. In a phase II clinical trial, Correale and colleagues showed that the combination of polychemotherapy with granulocyte macrophage colonystimulating (GM-CSF) factor and low-dose IL-2 in colorectal carcinoma patients, results in high number of objective responses and low toxicity [105].

There is one report on combination of hepatic trans-arterial chemotherapy with IFN $\gamma$ plus IL-2 in patients with advanced HCC [106]. The achieved objective responses highlight some biological effect of this treatment combination. In another study, when IL-2 was administered together with IFN $\gamma$ and GM-CSF to advanced HCC patients, clinical results were poor [107]. However, in spite of some stimulating results, the clinical development of IL-2 has been proved unsuitable because in parallel to their efficacy the results involved severe toxicity, including systemic vascular leak syndrome.

No trials were reported on the application of other cytokines such as IL-12, TNF $\alpha$, or TRAIL, known to have a potential effect against primary or metastatic liver cancer in humans. Nevertheless, concerns were raised following reports on the development of severe toxicity after systemic treatment with IL-12 or TNF $\alpha[108,109]$ in other type of tumors.

Although being able to obtain some positive outcomes in the treatment of liver tumors, systemic application of cytokines is accompanied by toxic effects which can be overcome by local delivery. A possible role of some of the immunostimulatory cytokines, e.g. IL-12, could be reasonable in the context of vaccination as an adjuvant administered at low doses.

\section{Immunostimulating monoclonal antibodies}

In the field of cancer therapy mAbs can act directly against tumor cells or indirectly by interfering with several processes such as survival, cellular proliferation or angiogenesis. The immunostimulating monoclonal antibodies which are those corresponding to the latter group, are defined as a new family of drugs aimed to augment immune responses. They consist in either agonistic or antagonistic mAbs which are aimed to bind key immune system receptors, thereby enhancing antigen presentation, providing co-stimulation or counteracting immune-regulation [110]. 


\section{Regulation of $\mathrm{T}$-cell responses}

T-cells express several co-signalling molecules, typically cell-surface glycoproteins classified as co-stimulators or co-inhibitors $[111,112]$. The outcome of T-cell responses depend on the balance between co-stimulatory and coinhibitory molecules. Thus, antigenic signalling in the absence of co-stimulatory molecules results in suboptimal immune activation and may lead to T-cell deletion or unresponsiveness. Monoclonal antibodies targeting costimulatory molecules expressed on T-cells may act agonistically, working as surrogate ligands and augmenting Tcell proliferation and survival. Alternatively, mAbs may act antagonistically, counteracting the inhibitory effects of co-inhibitor molecules or Treg-cells.

\section{Costimulation with agonistic mAbs}

Diverse costimulatory molecules appear to regulate T-cell response, working specifically at different time points $[113,114]$. Antibodies against CD28 are known to potentiate antitumor immunity in combination with bi-specific antibodies that bind to both the tumor antigen and the TCR-CD3 complex [112]. Some anti-CD28 antibodies, termed superagonist antibodies, can activate T-cells without concomitant TCR engagement. Unfortunately, concerns were raised following reports of severe toxicity in a Phase I dose-escalation trial with an anti-CD28 mAb (TGN1412) [115].

Another costimulatory molecule, CD137 (also known as 4$1 \mathrm{BB})$, is a member of the TNF-receptor superfamily, expressed in antigen-activated T-cells (CD4+, CD8+, Treg and NK cells), DCs, cytokine-activated NK cells, eosinophils, mast cells and, intriguingly, endothelial cells of some metastatic tumors [116-118]. The natural ligand for CD137 (CD137 ligand) is constitutively produced by activated APCs. Agonistic anti-CD137 Abs strongly promote survival of T-cells and prevent activation-induced cell death $[119,120]$. Antitumor effects of anti-CD137 mAbs were first recognized by Melero et al. [121] in established Ag104 sarcoma and P815 mastocytoma. These effects are thought to be involved in the activation of naive T-cells which are specific for tumor antigens cross-presented by DCs. Repeated systemic injections of agonistic anti-CD137, in two mouse models of CRC, induced tumor eradication in 3 out of 5 mice [122]. Unfortunately, this therapeutic modality may have serious drawbacks. Niu and colleagues found that a single injection of anti-CD137 given to BALB/c or $\mathrm{C} 57 \mathrm{BL} / 6$ control mice led to the development of a series of anomalies such as splenomegaly, lymphadenopathy, hepatomegaly, multifocal hepatitis, anemia, altered trafficking of B cells and CD8+ T-cells, loss of NK cells, and a 10 -fold increase in bone marrow cells bearing the phenotype of hematopoietic stem cells [123].

OX40 (also known as CD134 and TNR4) is another member of the TNF receptor family, specifically expressed in activated CD4+ and CD8+ T lymphocyte, B-cells, DCs and eosinophils [124]. OX40 ligand (OX40L) is expressed in activated APCs and can also be found in activated T-cells and in endothelial cells [125]. OX40 seems to be particularly important to ensure T-cell long-term survival, probably through up-regulation of the anti-apoptotic proteins Bcl-xL and Bcl-2 [126]. Weinberg [127] showed that systemic OX40 ligation increases tumor immunity, with a role for CD4+ cells in the B16 melanoma model. Phase I clinical trials, using a murine anti-human OX40 mAb, have been initiated in patients with advanced cancer of multiple tissue origins; however, it can not be administered in several repeated doses because of its xenogeneic nature, which is likely to trigger immune responses against murine sequences [128].

Thus, agonistic mAbs have been found to produce some benefits in treatment of liver tumors although their systemic application causes serious undesired secondary effects. Intratumoral application of low doses of them might overcome some of the systemic delivery problems.

\section{Counteracting immunoregulation with antagonistic $\mathbf{m A b s}$}

The cytotoxic T-lymphocyte-associated protein 4 (CTLA-4, also known as CD152) is an inhibitory receptor with a structural homology to the co-stimulatory receptor CD28 $[111,129]$. Under antigenic stimulation, ligand binding to CTLA-4 generates inhibitory signals mediating reduction in T-cell proliferation and in IL-2 secretion. Administration of antagonistic anti-CTLA-4 mAbs demonstrated antitumor effects in different murine tumor models including colon, prostate and renal carcinomas, as well as fibrosarcoma and lymphoma [130,131].

As mentioned earlier, PD-1 and its ligands B7-H1 (also known as PD-L1) and B7-DC (also known as PD-L2) $[111,132]$ deliver inhibitory signals to T cells. Administration of mAbs anti-PD-1 and B7-H1 produced CTL-mediated antitumor effects in mice [133].

The finding that HCC-associated antigen HAb18G/ CD147, a member of the CD147 family, enhances tumor invasion and metastasis through induction of matrix metalloproteinases [134] led to the development of an antiCD147 therapy. By using an orthotopic model of HCC in nude mice, $\mathrm{Ku}$ and colleagues [135] showed that the application of two different anti-CD147 mAbs (HAb18 and LICARTIN) resulted in consistent inhibition of both tumor and metastasis growth.

In animal models, immunostimulatory mAbs antitumor effects were demonstrated when used either alone or in combination with radiotherapy or chemotherapy $[136,137]$. Clinical experience with mAbs is scarce; however, several immunostimulatory mAbs have now been introduced in clinical trials and early results suggest that 
they might enhance antitumor responses with accepted toxicity. Therapy with immunostimulatory antibodies alone or in combination with other strategies should be carefully designed in order to avoid induction of autoimmune toxicity as a consequence of uncontrolled stimulation of the immune system effector arm.

\section{Gene transfer of cytokines and costimulatory molecules. Genetic vaccination}

Gene therapy is a promising novel therapeutic strategy for treatment of several heritable and non-heritable human diseases $[138,139]$. Since about 20 years ago, when the first clinical trial was initiated, and after more than 1300 clinical trials performed all around the world http:// www.wiley.co.uk/genmed/clinical/, we learned that the core concept of gene therapy may be applicable: genes introduced into patients can be safely expressed [140]. However, we have also learned that vector efficiency in clinical applications is not as good as expected [141,142]. Cancer represents almost $70 \%$ of the clinical trials conducted in patients and $25 \%$ of these studies consisted in the application of cytokine genes.

Gene transfer of immunostimulatory cytokines (e.g. IL-2, IL-4, IL-6, IL-7; IL-12, INF- $\gamma$, TNF- $\alpha$, GM-CSF) was shown to overcome the immune tolerance against tumors, facilitating their eradication in some cases [143-145] (Table 2). Two main approaches have been used [144]: i) direct injection of vectors expressing cytokines/chemokines/costimulatory molecules into tumor lesions, or ii) use of tumor cells/DCs transduced ex vivo with vectors expressing cytokines/costimulatory molecules.

Interleukin 12 (IL-12) is a potent cytokine that showed antitumor activity in a number of tumor models $[146,147]$. Multiple action mechanisms mediating its activity are known, including the activation of NK cells, cytotoxic T lymphocytes and the induction of a TH1 type of response [146]. It also inhibits tumor angiogenesis and enhances the expression of adhesion molecules on endothelial cells, thus facilitating the homing of activated lymphocytes to the tumor $[148,149]$. However, IL- 12 was shown to eventually induce severe toxicity when administered systemically as a recombinant protein [150]. Thus, unspecific toxic effects of systemic IL-12 administration might be solved by the use of gene therapy strategies, allowing local production of IL-12 at the tumor milieu and resulting in high local levels with low systemic concentrations [151]. Consistently, the potential usefulness of IL-12 gene transfer for liver tumors treatment in animal models was demonstrated by different groups including ours [152-154]. We also reported that intratumor injection of an adenovirus encoding IL-12 genes (AdIL-12) into rats with orthotopic HCC induced the complete tumor elimination in the majority of animals [155]. Potent effects of this vector have also been shown in a very aggressive multifocal HCC model developed in rats, by treatment with DENA $[155,156]$ as well as in mice bearing hepatic metastases of colorectal carcinoma $[157,158]$ and in woodchucks chronically infected with woodchuck hepatitis virus (WHV) [159]. The toxicity observed under high

Table 2: Gene transfer immunostimulatory molecules.

\begin{tabular}{|c|c|c|}
\hline Cytokine & Mechanism & Ref. \\
\hline IL-2 + IL-12 & CTLs & 149 \\
\hline IL-10 & CD8+ & 152 \\
\hline IL-12 & NK, CD4+, CD8+ & 187 \\
\hline IL-12+IL-10 & NK, CD4+, CD8+, Macrophages, Neutrophils & 165 \\
\hline IL-2 & CTLs & 166 \\
\hline HLA-B7 & CTLs & 167 \\
\hline $\mathrm{IL}-12+\mathrm{IP}-10$ & $\mathrm{CD} 8+, \mathrm{CD} 4+, \mathrm{NK}$ & 161 \\
\hline $\mathrm{IL}-\mathrm{I} 2+\mathrm{MIP} 3 \alpha$ & $\mathrm{CD} 8+, \mathrm{CD} 4+, \mathrm{NK}$ & 162 \\
\hline CD40-L & CD8+ & 168,169 \\
\hline GM-CSF + HSV & CD4+, CD8+ & $|7|$ \\
\hline
\end{tabular}

CTLs: Cytotoxic T lymphocytes; NK: Natural killer cells. 
IL-12 levels is partly due to induction of IFN- $\gamma$ overproduction [160]. An encouraging result is that IL-12 gene transfer in combination with another vector expressing the chemokine IP-10 (AdIP-10) allowed the reduction in the AdIL-12 dose with a similar outcome efficacy [161]. The underlying mechanism is the following: lymphocytes get attracted to tumors due to a local IP-10 expression and subsequently they are activated by IL-12. In addition, a combination of IL-12 with MIP3 $\alpha$ demonstrated similar synergistic antitumor effects [162].

The effects of IL-12 gene transfer were assessed in patients with advanced gastrointestinal carcinomas in a phase I clinical trial consisting mainly in liver tumors. Patients were administered with up to 3 intratumor injections of AdhIL-12[163]. Treatment feasibility and safety were studied. Even though maximal tolerated dose has not been reached, some evidence of biological and antitumor activities were observed. One partial response, two minor regressions and six stabilizations were achieved. In four out of 10 patients, a significant lymphocyte infiltrate was observed in injected tumors.

It has been stated that abnormal elevated levels of Th2 cytokines such as IL-10 are able to skew an immune response that favors tumor growth [164]. In contrast, Lopez et al. [165] have recently shown that tumor cell vaccines producing a combination of IL-10 and IL-12 act synergistically in eradicating established CRC, with the underlying mechanisms being not fully addressed.

Systemic injection of recombinant IL-2 used extensively in clinical oncology for patients with metastatic renal carcinoma and melanoma has shown low efficacy and high toxicity. A phase I-II clinical trial consisting in the administration of a recombinant adenovirus encoding for IL-2 gene was carried out in patients with advanced digestive carcinomas [166]. Only one of the treated patients showed a positive tumor response with necrosis of the tumor mass.

Molecules such as HLA-B7 are essential to promote specific T-cell responses. A reduced expression of MHC-I was observed in CRC. In an attempt to make CRC more visible to the immune system, Rubin et al [167] carried out a phase I clinical trial consisting in an indirect intralesional gene transfer of both HLA-B7 and $\beta 2$-microglobulin into CRC hepatic metastases. Treatment with a single plasmid construction encoding for both genes in a lipid formulation (Allovectin7) was feasible and safe in 15 patients, however, details regarding antitumor effect have not been reported. Such an approach could produce significant therapeutic improvements if aimed to deliver functionally relevant genes.

The interaction between CD40 ligand (CD40L, CD154) and its receptor CD40, expressed in DCs, is essential for the initiation of cellular and humoral immune responses. Gene transfer of CD40-L led to regression of established CRC [168] and HCC [169] in a CD8+ T cell dependent manner.

Replication-selective viral agents (oncolytic virotherapy) hold promise as a novel cancer treatment platform. Oncolytic virotherapy is based on the ability of these vectors to selectively replicate in cancer cells as a result of different mechanisms of action [170]. This novel class of targeting viral vectors exerts direct antitumor effects, but can also be engineered to produce immunostimulatory genes, such as GM-CSF, augmenting its efficacy. A potent in vivo antitumor effect of an oncolytic vector carrying HSV and GMCSF genes has been demonstrated against murine CRC CT26 and murine HCC Hepa 1.6 [171].

The mutant adenovirus dl1520, also called ONYX-015, was the first described oncolytic adenovirus [172]. It contains a deletion in the E1B $55 \mathrm{~K}$ gene that achieves preferential replication in cancer cells by different mechanisms. In the case of liver tumors, this virus showed a partial antitumor effect on murine models but no evident antitumor effect was found when applied to HCC patients. Two separate clinical trials showed that ONYX-015 has limited therapeutic effect as monotherapy in patients with liver tumors, especially if systemic routes are used $[173,174]$. Other oncolytic adenoviruses have been developed, and show promising results in animal models of HCC. However, their performances in clinical trials have not been tested so far [175].

In conclusion, gene transfer of cytokines and the use of oncolytic viruses are two developing immunotherapy strategies which hold promise in treatment of liver tumors. The former strategy is being widely applied and after further improvements might assure sufficient tumor levels of inflammatory cytokines circumventing toxic systemic effects. The latter strategy is in early stages of development and it largely needs to be applied into the clinics.

\section{Immunotherapy with dendritic cells}

The armamentarium for immunotherapy protocols has been boosted by the identification of DCs as protagonists of antigen presentation [176]. The final outcome of DC cross-presentation could be either T-cell activation or Tcell tolerance, depending on its activation/maturation status [177]. Thus, while mature DCs are able to induce antitumor immunity, antigen presentation by immature DCs results in the induction of tolerance [177]. In addition, IL4 which is overexpressed in the liver under recurrent hepatitis C [178] was shown to influence DCs to induce CD4+ $\mathrm{T}$ cell differentiation into the Th2 lineage and to suppress DC response to IFN-gamma [179]. Up to now, several clinical studies consisting in the application of DCs were performed and, as a general outcome, no significant side 
effects were observed in the majority of these trials with important biological effects showing the augmentation of cellular immune responses against tumor antigens [180].

Direct injection of DCs into tumor tissue has been exploited experimentally and clinically with diverse results [181-183]. Chi KH and colleagues [184] conducted a phase I trial in patients with advanced HCC after conformal radiotherapy. Intratumoral injections of autologous immature naïve DCs prior and after radiotherapy resulted in 2 partial and 4 minor responses. Induction of specific immune responses against AFPs and enhancement in NK activity were observed.

DCs ex vivo-engineered to produce IL-12 were shown to induce antitumor immunity in mice $[182,183]$. Similar results were reported after application of DCs genetically modified to express IL-7 [185] or IL-15 [186]. A phase I clinical trial consisting in the intratumoral injection of autologous DCs, transfected with Ad-IL-12, in patients with metastatic gastrointestinal carcinomas was carried out [187]. This strategy was feasible and very well tolerated in doses up to $50 \times 10^{6} \mathrm{DCs}$. One partial response and 2 stabilizations were observed. In 3 out of 10 treated patients, a marked increased in CD8+ T lymphocyte infiltrates was found, and in 5 of them NK activity was significantly induced. One of the possible reasons behind the limited antitumor activity might be that DCs would likely be retained within the malignant tissue due to increased intratumoral levels of IL-8 expression as well as other chemotaxis signals, preventing their mobilization to the secondary lymphoid organs for further amplification of immune responses. Consistently, scintigraphic tracking of injected ${ }^{111}$ In-labelled DCs showed retention of DCs inside tumors [188].

As previously discussed, CD40-L is a costimulatory molecule expressed mainly on activated CD4+ T cells, which is essential for the initiation of antigen-specific T-cell responses [189]. Crystal and colleagues [190,191] showed elimination of CRC nodules after intratumoral administration of CD40-L exogenously expressing DCs. Although this approach has not yet been applied in clinical trials, it seems promising.

Another technique employed to load antigens to DCs consists in the cellular transfection with mRNA molecules. Chu et al. transfected total mRNA from CT26 CRC cells to DCs and showed strong specific CTL activity as well as protective immunity in vivo [192]. Immunization of CEA-transgenic mice, using mature DCs loaded with an anti-idiotype antibody that mimics CEA, resulted in a potent antitumor response against CEA-expressing CRCs, while immunization with DCs loaded with CEA showed less potent response [193]. Morse et al. reported a phase I clinical trial consisting in the administration of autolo- gous DCs loaded with CEA RNA (peptide CAP-1) into 21 patients with resected CRC liver metastases [194]. The procedure was well tolerated, one patient had a minor response, and one had stable disease. More recently, the same group carried out another phase I study in 14 patients (12 CRC and 2 non-small lung cancer) on the effects of immunotherapy combined with DCs transduced with a fowlpox vector encoding CEA and costimulatory molecules. Immunization of these patients was safe and it was able to activate potent CEA-specific immune responses. In a phase I clinical trial with the aim of increasing the amount of circulating DCs, Fong et al. incubated DCs with the hematopoietic growth factor Flt3 ligand before injecting DCs loaded with CEA-derived peptide into 12 patients with colon or non-small cell lung cancer [195]. Two patients showed objective responses and two had stable disease.

Stift and colleagues reported that vaccinations with autologous DCs pulsed with tumor lysates in a cohort of advanced cancer patients (including two with HCC) was safe and feasible [196]. Delayed-type hypersensitivity (DTH) skin test was positive in the majority of vaccination-treated patients and induction of IFN- $\gamma$ producing T cells was achieved in 4 other patients (not HCC). Another similar DC-based strategy was applied by Iwashita and colleagues [197]. They carried out a phase I clinical trial in patients with advanced HCC. DC-based strategy consisted in the subcutaneous injection of DC pulsed with tumor extract in 10 patients. One patient showed a partial response and in 2 of them AFP levels were decreased. Seven out of 10 showed positive DTH tests for KLH. Tamir and colleagues [198] evaluated the effectiveness of tumor-lysate loaded DC vaccines in the treatment of advanced CEA-positive CRCs.

Itoh et al. combined both DCs pulsed with a CEA peptide (restricted to HLA-A24) and adjuvant cytokines (IFN- $\alpha$ and TNF- $\alpha$ ) in the treatment of patients with CEA-expressing metastatic tumors [199]. Ten HLA-A24 patients with advanced digestive tract or lung cancer were treated. No significant adverse effects were observed and the disease in 2 positive DTH test was stabilized [200]. A few years later, Ueda and colleagues conducted a phase I clinical study in which DCs previously pulsed with a CEA-derived peptide were administered to HLA-A24-restricted patients. Eighteen compatible patients were enrolled. No severe toxicity was observed. In some patients, stabilization of the disease and decrease in CEA levels were reported. Accordingly, patients with clinical responses were positive in skin tests and developed specific CTLs [201]. Finally, Babatz and colleagues demonstrated that immunotherapy with DCs pulsed with a CEA-derived peptide is able to induce specific IFNgamma producing CD8+ T cells [202].

We and others have observed that DCs and NK cell interaction plays an important role in tumor immunity 
$[187,203,204]$. In this regard, Osada and colleagues found in patients with metastatic CRC that immunization with DCs transduced with a fowlpox vector encoding CEA was able to increase NK activity in 4 of 9 patients [205]. Importantly, increased NK activity was correlated with clinical response. In order to in vivo-activate DCs and thereby avoiding ex vivo manipulation, Furumoto et al. injected MIP3 $\alpha$ chemokine together with CpGs inside CRC tumors [206]. They observed an increase in DC number within tumors which were finally eradicated through the development of specific CTLs.

The use of cytokines as a vaccine adjuvant has been shown to be a promising option for cancer therapy, due to its potential effectiveness against disseminated disease without causing systemic toxicity [207-211]. However, the weakness of these strategies lies in: 1) the need of culturing autologous cancer cells from each patient, 2) the problems in the selection of positively modified cancer cells, 3 ) the lack of an efficient APC activity in tumor cells and, 4) the limited amount of tumor cells that precludes repeated immunizations. Investigators have looked into other strategies to carry cytokines genes or tumor antigens (such as the use of allogeneic tumor cell lines) but, unfortunately, allogeneic tumor cells may lack sole TAA present within the patient's own tumor, thus reducing its efficacy.

In conclusion, different strategies involving DCs have been developed during the lasts years. Although for some of them no clinical trials have been conducted yet, for other strategies a proportion of patients responded to treatment with minor tumor regression or stabilization, with variable induction of the immune response. Further studies are required for improving the benefits of manipulating the main kind of APCs involved in immune reactions.

\section{Contribution of adoptive T-cell therapy strategies}

In several animal models, solid tumors were shown to be susceptible to elimination after infusion of large amounts of tumor-specific T-lymphocytes [212]. However, the translation of these enthusiastic successes into patients are not yet feasible, partly due to difficulties in generating tumor antigen-specific T-cells ex vivo [213].

Adoptive therapy involves the transfer of ex vivo expanded and stimulated immune effector cells to tumor-bearing hosts, aiming at augmenting the antitumor immune response $[212,214]$. In general, adoptive therapy is accomplished by harvesting cells from the peripheral blood, tumor sites (tumor infiltrating lymphocytes), or draining lymph nodes from which, the effector cells could eventually be expanded ex vivo, in either a specific or non-specific fashion.

One of the major aims of the adoptive T-cell therapy is the identification of tumor-associated antigens (TAAs) that are ectopically expressed or overexpressed in tumor cells relative to normal tissues or, tumor-specific antigens (TSAs) that are expressed exclusively in tumor cells. Despite aberrant expression of TAAs in tumor cells, many of these proteins are also expressed at some level in nonmalignant adult tissues and, as a consequence, the immune system may recognize TAAs as self-antigens and limit the T-cell immune response. In addition, as previously discussed the liver immune system usually generates tolerance to proteins expressed by its own cells and HCC induces immune response suppression [215]. Moreover, it was demonstrated that many malignant tumors find the way of down-regulating, modifying or losing its own antigens, in order to avoid immune recognition [29].

No TSA with high prevalence have been identified for liver tumors, so far. PLAC-1, which in normal tissues is only expressed in placenta, was recently found to be expressed in $1 / 3^{\text {rd }}$ to $1 / 4^{\text {th }}$ of the analyzed human HCC samples and $3,8 \%$ of patients were shown to present humoral responses against this antigen [216]. Among TAAs described in HCC the most important one is AFP. Several AFP-based immunotherapeutic approaches have been applied against HCC $[217,218]$. Additional TAAs recently found to be expressed in HCC are several members of the tumor-specific "cancer-testis" antigens (the MAGE, GAGE and BAGE genes, NY-ESO, CTA, TSPY and FATE/BJ-HCC2, among others) [219-221];, Aurora-A [222], SCCA [223], and Glypican-3. In between them, Glypican-3, a specific immunomarker for HCC that can be used to distinguish it from benign hepatocellular mass lesions, is highly immunogenic in mice and can induce effective antitumor immunity with no evidence of autoimmunity [224]. Several TAA antigens are also known for CRC liver tumors, including CEA and CP1 [225]. Clinical studies must be conducted in order to evaluate the potential use of these antigens in immunotherapy for liver tumors.

The lack of TSAs for HCC may be the most important limit to immunotherapy applications aimed to specifically target liver tumor cells. Several technological strategies such as serologic recombinant expression cloning (SEREX), gene expression profiling and proteomics, are being applied to discover any of those specific markers [226] but, until now, the results are limited [227].

Another important negative factor limiting the success of this type of immunotherapy is the low survival of adoptively transferred T-lymphocytes in cancer patients is. Currently, some strategies are being evaluated to increase the proliferation rate of transferred T-cells, including pretreatment with cyclophosphamide [228].

$\mathrm{T}$ cells are the cellular model predominantly chosen for adoptive cellular therapy, although a role for NK cells and other cytokine-induced lymphocytes have also been 
investigated. Pilot clinical trials of adoptive T cell immunotherapy were initiated in cancer soon after the discovery of IL-2 (in the late 1970s), which enabled large-scale culture of T cells [229]. Although certain clinical success has been observed in melanoma, renal cancer, and lymphoma $[230,231]$, phase II studies in HCC patients have shown objective response rates of only about $20 \%[232,233]$.

To date, no randomized clinical trials, but one, had demonstrated efficacy of adoptive $\mathrm{T}$ cell transfer approaches. Takayama et al. [234] reported benefits of adoptive transfer with an adjuvant setting for HCC after surgical resection of the primary tumor. In this study, autologous peripheral blood $\mathrm{T}$ cells were pre-cultured in medium supplemented with CD3-specific antibody and IL-2, and cell infusion was shown to reduce the risk of cancer recurrence by $41 \%$ when compared to a control group receiving only surgery. However, this trial remains unconfirmed, and the mechanism involved in the antitumoral effect remains unknown.

In order to enhance the effector capacity of tumor-specific $\mathrm{T}$ cells, different cytokines such as IL-18 and IL-12, were tested as potential biological response modifiers in the setting of adoptive immunotherapy. Nakamori et al. [235] demonstrated that adoptive transfer of IL-18-transduced cytotoxic T-lymphocytes in combination with IL-12 showed marked inhibitory effects on primary tumors and metastasis in a mouse model of orthotopic CRC.

\section{Synergistic effect of combined therapy}

Combinatorial strategies against cancer could either consist in a simultaneous application of different immunotherapeutic approaches or in a combination of classic chemo- or radio-therapeutic protocols with immunologic tools. Some chemotherapeutical agents were shown to induce upregulation of tumor-associated antigen expression (such as CEA) or to reduce tumor cell resistance to specific cytotoxic T lymphocytes. Some of these combinations have been found to produce synergistic rather than additive effects.

The immune-inhibitory mechanisms developed by tumor cells, such as overproduction of immunosuppressive cytokines (TGF- $\beta$ and IL-10) or induction of Treg cells, are important obstacles that a successful cancer immunotherapy strategy has to face. Inhibition of one or more of these mechanisms appear to be a good strategy to induce antitumor immunity [236]. Elimination or inhibition of Treg activity by low-dose cyclophosphamide [237] or antibodies against CD25 or CTLA-4 may modify tumor immunosuppressive microenvironment, thereby increasing the efficacy of immunotherapy.

It has been shown, both in mice and humans, that pretreatment with cyclophosphamide, known to induce lym- phodepletion, results in a sustained function of adoptively transferred T-cells. Adoptive transfer efficacy can also be enhanced by alternative immunotherapies such as cytokine administration [238] and in some cases by standard cytotoxic chemotherapy and radiotherapy $[239,240]$.

Preclinical models support the rationale for combining cancer vaccines with conventional therapies, such as radiation, chemotherapy, surgery, hormone therapy, as well as other immunotherapies. One of the most promising results was obtained from clinical trials combining antibodies against CTLA- 4 with other immunotherapies such as application of GM-CSF-transduced tumor-cell vaccines. This treatment resulted in the alteration of the intratumor balance of Tregs-T effector cells and in tumor rejection [241]. Further research is required to optimize the combination of different immunotherapies to obtain maximal clinical benefits.

\section{What have we learned from the clinic? Conclusion}

Conducting immunotherapy clinical trials in patients with liver tumors is challenging and several strategies have been opened for clinical applications. However, the high efficacy of different immunotherapy strategies at eliminating liver tumors in animal models is in contrast with the very limited results achieved in patients. There are many explanations to why immunotherapy strategies fail or have little impact on patient survival. In general, for all solid tumors, the common scenario chosen to test immunotherapeutic protocols almost always involves patients with advanced diseases that precludes, or at least decreases, the possibility of success. Then, due to the advanced status of the cancer disease, the immune system of the majority of treated patients is deteriorated and unable to recognize tumor antigens. For the specific case of HCC and partially to CRC liver tumors, apart from the immunological privilege status of the liver, there are some particular aspects that add further difficulties when aiming for a clinical response such as the immunosuppressant effect of chronic HBV/HCV infection on cells of the immune system (e.g. DCs) or complications derived from developed cirrhosis which usually undermine efforts to stimulate the immune response. There is a general agreement in that different forms of immunotherapy should be tested for overall clinical benefits along with conventional treatment regimens evidencing improvements in survival. It would be desirable to evaluate the possibility of immunotherapy strategies as neoadjuvancy in patients at early stages of the disease such as after surgical removal of HCC and hepatic metastases of $\mathrm{CRC}$, two diseases with increased likelihood of recurrence. Finally, new ways of long-term local delivery of signals inducing CD4+ T cell differentiation towards the Th1 lineage or vaccination against liver tumor antigens would eventually overcome 
the drawbacks of the pro-tolerogenic liver influence and the impairment or reduced immune response capacity caused by $\mathrm{HBV} / \mathrm{HCV}$ viruses.

\section{Competing interests}

The authors declare that they have no competing interests.

\section{Authors' contributions}

MP and VR: The immune system and the induction of antitumor immunity - basic concepts; Contribution of adoptive T-cell therapy strategies. JBA: The liver: an immunological privileged organ. OGS and JBA: Immunostimulating monoclonal antibodies. LA and MM: Immunotherapy with dendritic cells. GM: Introduction; The liver: an immunological privileged organ; Systemic use of immunostimulatory cytokines; Gene transfer of cytokines and costimulatory molecules; Genetic vaccination; Conclusions.

MG did a deep revision of the English grammar and style because English is not our native language. CA constructed the figure and the tables. MS was involved in the analysis and revision of the data included in the paper. GM outlined the topics of the manuscript and invited to each author to write specific chapters of the paper. All authors read and approved the final manuscript.

\section{Acknowledgements}

We would like to thank Miguel Rizzo and Soledad Arregui for their technical assistance. GM work is supported in part by grants from Agencia Nacional de Promoción Científica y Tecnológica (ANPCyT) (PICT-2005/ 34788 and PICTO-CRUP-2005/3I I79), Agencia Española de Cooperación Internacional and Programa Bicentenario-Banco Mundial, Conicyt, Chile CTE-06 (MG). LA work is supported in part by Mitzutani Foundation. CA and MM are fellows from ANPCyT. GM acknowledges the continuous support of Mrs. Ines Bemberg.

\section{References}

I. Parkin DM, Bray F, Ferlay J, Pisani P: Global cancer statistics, 2002. CA Cancer J Clin 2005, 55:74-108.

2. El-Serag HB, Mason AC: Rising Incidence of Hepatocellular Carcinoma in the United States. N Engl J Med I999, 340:745-750.

3. El-Serag HB, Marrero JA, Rudolph L, Reddy KR: Diagnosis and treatment of hepatocellular carcinoma. Gastroenterology 2008, |34:1752-1763.

4. Llovet JM, Burroughs A, Bruix J: Hepatocellular carcinoma. Lancet 2003, 362:1907-1917.

5. Bruix J, Sherman M, Llovet JM, Beaugrand M, Lencioni R, Burroughs AK, Christensen E, Pagliaro L, Colombo M, Rodes J: Clinical management of hepatocellular carcinoma. Conclusions of the Barcelona-2000 EASL conference. European Association for the Study of the Liver. J Hepatol 200I, 35:42I-430.

6. Bruix J, Sherman M: Management of hepatocellular carcinoma. Hepatology 2005, 42: I 208-1236.

7. Weitz J, Koch M, Debus J, Hohler T, Galle PR, Buchler MW: Colorectal cancer. Lancet 2005, 365: 153-165.

8. Cummings LC, Payes JD, Cooper GS: Survival after hepatic resection in metastatic colorectal cancer: a population-based study. Cancer 2007, 109:718-726.

9. Lorenz M, Staib-Sebler E, Hochmuth K, Heinrich S, Gog C, Vetter G, Encke A, Muller HH: Surgical resection of liver metastases of colorectal carcinoma: short and long-term results. Semin Oncol 2000, 27: 1 12-119.
10. Stang| R, Altendorf-Hofmann A, Charnley RM, Scheele J: Factors influencing the natural history of colorectal liver metastases. Lancet 1994, 343:1405-1410.

II. de Gramont A, Figer A, Seymour M, Homerin M, Hmissi A, Cassidy J, Boni C, Cortes-Funes H, Cervantes A, Freyer G, et al.: Leucovorin and fluorouracil with or without oxaliplatin as first-line treatment in advanced colorectal cancer. J Clin Oncol 2000, 18:2938-2947.

12. Douillard JY, Cunningham D, Roth AD, Navarro M, James RD, Karasek P, Jandik P, Iveson T, Carmichael J, Alakl M, Gruia G, Awad L, Rougier P: Irinotecan combined with fluorouracil compared with fluorouracil alone as first-line treatment for metastatic colorectal cancer: a multicentre randomised trial. Lancet 2000, 355:104I-1047.

13. Goldberg RM, Sargent DJ, Morton RF, Fuchs CS, Ramanathan RK, Williamson SK, Findlay BP, Pitot HC, Alberts SR: A randomized controlled trial of fluorouracil plus leucovorin, irinotecan, and oxaliplatin combinations in patients with previously untreated metastatic colorectal cancer. J Clin Oncol 2004, 22:23-30.

14. Saltz LB, Cox JV, Blanke C, Rosen LS, Fehrenbacher L, Moore MJ, Maroun JA, Ackland SP, Locker PK, Pirotta N, Elfring GL, Miller LL: Irinotecan plus fluorouracil and leucovorin for metastatic colorectal cancer. Irinotecan Study Group. N Engl J Med 2000, 343:905-914.

15. Hurwitz H, Fehrenbacher L, Novotny W, Cartwright T, Hainsworth J, Heim W, Berlin J, Baron A, Griffing S, Holmgren E, Ferrara N, Fyfe G, Rogers B, Ross R, Kabbinavar F: Bevacizumab plus irinotecan, fluorouracil, and leucovorin for metastatic colorectal cancer. N Engl J Med 2004, 350:2335-2342.

16. Cunningham D, Humblet $Y$, Siena $S$, Khayat D, Bleiberg $H$, Santoro $A$ Bets D, Mueser M, Harstrick A, Verslype C, Chau I, Van Cutsem E: Cetuximab monotherapy and cetuximab plus irinotecan in irinotecan-refractory metastatic colorectal cancer. $N$ Engl J Med 2004, 35 I:337-345.

17. Berzofsky JA, Terabe M, Oh S, Belyakov IM, Ahlers JD, Janik JE, Morris JC: Progress on new vaccine strategies for the immunotherapy and prevention of cancer. J Clin Invest 2004, I 13:1515-1525.

18. Gilboa E: The promise of cancer vaccines. Nat Rev Cancer 2004, 4:40I-4II.

19. Unitt E, Marshall A, Gelson W, Rushbrook SM, Davies S, Vowler SL, Morris LS, Coleman N, Alexander GJ: Tumour lymphocytic infiltrate and recurrence of hepatocellular carcinoma following liver transplantation. J Hepatol 2006, 45:246-253.

20. Naito $Y$, Saito K, Shiiba K, Ohuchi A, Saigenji K, Nagura H, Ohtani H: CD8+ $T$ cells infiltrated within cancer cell nests as a prognostic factor in human colorectal cancer. Cancer Res 1998, 58:349I-3494.

2I. Galon J, Costes A, Sanchez-Cabo F, Kirilovsky A, Mlecnik B, LagorcePagès C, Tosolini M, Camus M, Berger A, Wind $P$, Zinzindohoué $F$, Bruneval $P$, Cugnenc PH, Trajanoski Z, Fridman WH, Pagès F: Type, density, and location of immune cells within human colorectal tumors predict clinical outcome. Science 2006, 313:1960-1964.

22. Bertoletti $A$, Ferrari $C$ : Kinetics of the immune response during HBV and HCV infection. Hepatology 2003, 38:4-I3.

23. Rehermann B, Nascimbeni M: Immunology of hepatitis B virus and hepatitis C virus infection. Nat Rev Immunol 2005, 5:2 I 5-229.

24. Dustin LB, Rice CM: Flying under the radar: the immunobiology of hepatitis C. Annu Rev Immunol 2007, 25:7I-99.

25. Rosenberg SA: Progress in human tumour immunology and immunotherapy. Nature 200I, 4I I:380-384.

26. Shankaran V, Ikeda H, Bruce AT, White JM, Swanson PE, Old LJ, Schreiber RD: IFNgamma and lymphocytes prevent primary tumour development and shape tumour immunogenicity. Nature 200I, 4I 0: II07-IIII.

27. Dunn GP, Old LJ, Schreiber RD: The three Es of cancer immunoediting. Annu Rev Immunol 2004, 22:329-360.

28. Zhang L, Conejo-Garcia JR, Katsaros D, Gimotty PA, Massobrio M, Regnani G, Makrigiannakis A, Gray H, Schlienger K, Liebman MN, Rubin SC, Coukos G: Intratumoral T cells, recurrence, and survival in epithelial ovarian cancer. N Engl J Med 2003, 348:203-2।3.

29. Croci DO, Zacarias Fluck MF, Rico MJ, Matar P, Rabinovich GA, Scharovsky OG: Dynamic cross-talk between tumor and immune 
cells in orchestrating the immunosuppressive network at the tumor microenvironment. Cancer Immunol Immunother 2007, 56: $1687-1700$.

30. Rivoltini L, Carrabba M, Huber V, Castelli C, Novellino L, Dalerba P, Mortarini R, Arancia G, Anichini A, Fais S, Parmiani G: Immunity to cancer: attack and escape in $T$ lymphocyte-tumor cell interaction. Immunol Rev 2002, I 88:97-II3.

31. Zou W: Regulatory $\mathbf{T}$ cells, tumour immunity and immunotherapy. Nat Rev Immunol 2006, 6:295-307.

32. Nattermann J, Zimmermann H, Iwan A, von Lilienfeld-Toal M, Leifeld L, Nischalke HD, Langhans B, Sauerbruch T, Spengler U: Hepatitis C virus E2 and CD8I interaction may be associated with altered trafficking of dendritic cells in chronic hepatitis $\mathbf{C}$. Hepatology 2006, 44:945-954.

33. Liu B, Woltman AM, Janssen HL, Boonstra A: Modulation of dendritic cell function by persistent viruses. J Leukoc Biol 2008 , 85(2):205-2| 4 .

34. Burnet FM: The concept of immunological surveillance. Prog Exp Tumor Res 1970, 13:1-27.

35. Thomas L: On immunosurveillance in human cancer. Yale J Biol Med 1982, 55:329-333.

36. Dunn GP, Old LJ, Schreiber RD: The immunobiology of cancer immunosurveillance and immunoediting. Immunity 2004, 2I:137-|48.

37. Luth S, Huber S, Schramm C, Buch T, Zander S, Stadelmann C, Bruck W, Wraith DC, Herkel J, Lohse AW: Ectopic expression of neural autoantigen in mouse liver suppresses experimental autoimmune neuroinflammation by inducing antigen-specific Tregs. J Clin Invest 2008, I I 8:3403-34I0.

38. Abe M, Thomson AW: Antigen processing and presentation in the liver. In Liver Immunology: Principles and Practice Edited by: Gershwin ME, Vierling JM, Manns MP. Totowa: Humana Press Inc; 2007:486.

39. Kamada N, Davies HS, Roser B: Reversal of transplantation immunity by liver grafting. Nature I98I, 292:840-842.

40. Seyfert-Margolis V, Turka LA: Marking a path to transplant tolerance. J Clin Invest 2008, I I 8:2684-2686.

4I. Diamantis I, Boumpas DT: Autoimmune hepatitis: evolving concepts. Autoimmun Rev 2004, 3:207-2I4.

42. Voehringer D, Blaser C, Grawitz AB, Chisari FV, Buerki K, Pircher H: Break of $T$ cell ignorance to a viral antigen in the liver induces hepatitis. J Immunol 2000, I 65:24I5-2422.

43. Lang KS, Georgiev P, Recher M, Navarini AA, Bergthaler A, Heikenwalder $M$, Harris NL, Junt T, Odermatt B, Clavien PA, Pircher $H$, Akira S, Hengartner $H$, Zinkernagel RM: Immunoprivileged status of the liver is controlled by Toll-like receptor 3 signaling. J Clin Invest 2006, I I 6:2456-2463.

44. Limmer A, Sacher T, Alferink J, Kretschmar M, Schonrich G, Nichterlein T, Arnold B, Hammerling GJ: Failure to induce organ-specific autoimmunity by breaking of tolerance: importance of the microenvironment. Eur J Immunol 1998, 28:2395-2406.

45. Crispe IN: Hepatic T cells and liver tolerance. Nat Rev Immunol 2003, 3:51-62.

46. Bissell DM, Wang SS, Jarnagin WR, Roll FJ: Cell-specific expression of transforming growth factor-beta in rat liver. Evidence for autocrine regulation of hepatocyte proliferation. J Clin Invest 1995, 96:447-455.

47. De Creus A, Abe M, Lau AH, Hackstein H, Raimondi G, Thomson AW: Low TLR4 expression by liver dendritic cells correlates with reduced capacity to activate allogeneic $\mathbf{T}$ cells in response to endotoxin. J Immunol 2005, I 74:2037-2045.

48. Pillarisetty VG, Shah AB, Miller G, Bleier JI, DeMatteo RP: Liver dendritic cells are less immunogenic than spleen dendritic cells because of differences in subtype composition. J Immunol 2004, 172:1009-1017.

49. De Minicis S, Seki E, Uchinami H, Kluwe J, Zhang Y, Brenner DA, Schwabe RF: Gene expression profiles during hepatic stellate cell activation in culture and in vivo. Gastroenterology 2007, I32:1937-1946.

50. Friedman SL: Liver fibrosis - from bench to bedside. J Hepatol 2003, 38(Suppl I):S38-53.

5I. Muhanna N, Horani A, Doron S, Safadi R: Lymphocyte-hepatic stellate cell proximity suggests a direct interaction. Clin Exp Immunol 2007, I 48:338-347.

52. Viñas $O$, Bataller R, Sancho-Bru $P$, Ginès $P$, Berenguer $C$, Enrich $C$, Nicolás JM, Ercilla G, Gallart T, Vives J, Arroyo V, Rodés J: Human hepatic stellate cells show features of antigen-presenting cells and stimulate lymphocyte proliferation. Hepatology 2003 , 38:919-929.

53. Muhanna N, Doron S, Wald O, Horani A, Eid A, Pappo O, Friedman SL, Safadi R: Activation of hepatic stellate cells after phagocytosis of lymphocytes: A novel pathway of fibrogenesis. Hepatology 2008, 48:963-977.

54. Bain C, Fatmi A, Zoulim F, Zarski JP, Trepo C, Inchauspe G: Impaired allostimulatory function of dendritic cells in chronic hepatitis C infection. Gastroenterology 2001, 1 20:512-524.

55. Sarobe P, Lasarte I], Zabaleta A, Arribillaga L, Arina A, Melero I, Borras-Cuesta $F$, Prieto J: Hepatitis $C$ virus structural proteins impair dendritic cell maturation and inhibit in vivo induction of cellular immune responses. J Virol 2003, 77: I0862-I087 I.

56. Waggoner $\mathrm{SN}$, Hall CH, Hahn YS: HCV core protein interaction with $\mathrm{gCl}$ q receptor inhibits Th I differentiation of CD4+ $\mathrm{T}$ cells via suppression of dendritic cell IL- 12 production. J Leukoc Biol 2007, 82: |407-|4| 9.

57. Zimmermann M, Flechsig C, La Monica N, Tripodi M, Adler G, Dikopoulos $\mathrm{N}$ : Hepatitis $\mathbf{C}$ virus core protein impairs in vitro priming of specific $T$ cell responses by dendritic cells and hepatocytes. J Hepatol 2008, 48:5I-60.

58. Duan XZ, Zhuang H, Wang M, Li HW, Liu JC, Wang FS: Decreased numbers and impaired function of circulating dendritic cell subsets in patients with chronic hepatitis B infection (R2). J Gastroenterol Hepatol 2005, 20:234-242.

59. Kanto T, Inoue M, Miyatake H, Sato A, Sakakibara M, Yakushijin T, Oki C, Itose I, Hiramatsu N, Takehara T, Kasahara A, Hayashi N: Reduced numbers and impaired ability of myeloid and plasmacytoid dendritic cells to polarize $T$ helper cells in chronic hepatitis C virus infection. J Infect Dis 2004, I 90:1919-1926.

60. Wertheimer AM, Bakke A, Rosen HR: Direct enumeration and functional assessment of circulating dendritic cells in patients with liver disease. Hepatology 2004, 40:335-345.

61. Ninomiya T, Akbar SM, Masumoto T, Horiike N, Onji M: Dendritic cells with immature phenotype and defective function in the peripheral blood from patients with hepatocellular carcinoma. J Hepatol 1999, 31:323-331.

62. Curtin JF, Cotter TG: Live and let die: regulatory mechanisms in Fas-mediated apoptosis. Cell Signal 2003, I 5:983-992.

63. Griffith TS, Yu X, Herndon JM, Green DR, Ferguson TA: CD95induced apoptosis of lymphocytes in an immune privileged site induces immunological tolerance. Immunity 1996, 5:7-16.

64. Ohshima K, Nakashima M, Sonoda K, Kikuchi M, Watanabe T: Expression of RCASI and FasL in human trophoblasts and uterine glands during pregnancy: the possible role in immune privilege. Clin Exp Immunol 200I, I 23:48I -486.

65. Griffith TS, Ferguson TA: The role of FasL-induced apoptosis in immune privilege. Immunol Today 1997, I 8:240-244.

66. Song E, Chen J, Ouyang N, Su F, Wang M, Heemann U: Soluble Fas ligand released by colon adenocarcinoma cells induces host lymphocyte apoptosis: an active mode of immune evasion in colon cancer. Br J Cancer 2001, 85:1047-1054.

67. Li M, Liu X, Zhou S, Li P, Li G: Effects of alpha fetoprotein on escape of Bel 7402 cells from attack of lymphocytes. BMC Cancer 2005, 5:96.

68. Li MS, Ma QL, Chen Q, Liu XH, Li PF, Du GG, Li G: Alpha-fetoprotein triggers hepatoma cells escaping from immune surveillance through altering the expression of Fas/FasL and tumor necrosis factor related apoptosis-inducing ligand and its receptor of lymphocytes and liver cancer cells. World J Gastroenterol 2005, I I:2564-2569.

69. He YF, Zhang GM, Wang XH, Zhang H, Yuan Y, Li D, Feng ZH: Blocking programmed death-I ligand-PD-I interactions by local gene therapy results in enhancement of antitumor effect of secondary lymphoid tissue chemokine. J Immunol 2004, 173:4919-4928.

70. Rubinstein N, Alvarez M, Zwirner NW, Toscano MA, Ilarregui JM, Bravo A, Mordoh J, Fainboim L, Podhajcer OL, Rabinovich GA: Targeted inhibition of galectin-I gene expression in tumor cells results in heightened $\mathrm{T}$ cell-mediated rejection; $\mathrm{A}$ potential mechanism of tumor-immune privilege. Cancer Cell 2004, 5:24l-25I.

7I. Rabinovich GA, Rubinstein N, Matar P, Rozados V, Gervasoni S, Scharovsky GO: The antimetastatic effect of a single low dose of 
cyclophosphamide involves modulation of galectin-I and Bcl-2 expression. Cancer Immunol Immunother 2002, 50:597-603.

72. Kondoh N, Hada A, Ryo A, Shuda M, Arai M, Matsubara O, Kimura F, Wakatsuki T, Yamamoto M: Activation of Galectin-I gene in human hepatocellular carcinoma involves methylation-sensitive complex formations at the transcriptional upstream and downstream elements. Int J Oncol 2003, 23:1575- I583.

73. Cao M, Cabrera R, Xu Y, Firpi R, Zhu H, Liu C, Nelson DR: Hepatocellular carcinoma cell supernatants increase expansion and function of CD4(+)CD25(+) regulatory T cells. Lab Invest 2007, 87:582-590.

74. Kobayashi N, Hiraoka N, Yamagami W, Ojima H, Kanai Y, Kosuge T, Nakajima A, Hirohashi S: FOXP3+ regulatory $T$ cells affect the development and progression of hepatocarcinogenesis. Clin Cancer Res 2007, I3:902-9II.

75. Kurokohchi K, Carrington M, Mann DL, Simonis TB, Alexander-Miller MA, Feinstone SM, Akatsuka T, Berzofsky JA: Expression of HLA class I molecules and the transporter associated with antigen processing in hepatocellular carcinoma. Hepatology 1996, 23:1181-1188.

76. Fujiwara K, Higashi T, Nouso K, Nakatsukasa H, Kobayashi $Y$, Uemura M, Nakamura S, Sato S, Hanafusa T, Yumoto Y, Naito I, Shiratori Y: Decreased expression of B7 costimulatory molecules and major histocompatibility complex class-I in human hepatocellular carcinoma. J Gastroenterol Hepatol 2004, I 9: | |2|-| | 27.

77. Matsui M, Machida S, Itani-Yohda T, Akatsuka T: Downregulation of the proteasome subunits, transporter, and antigen presentation in hepatocellular carcinoma, and their restoration by interferon-gamma. J Gastroenterol Hepatol 2002, 17:897-907.

78. Chiu CT, Yeh TS, Hsu JC, Chen MF: Expression of Bcl-2 family modulated through p53-dependent pathway in human hepatocellular carcinoma. Dig Dis Sci 2003, 48:670-676.

79. Fields AC, Cotsonis G, Sexton D, Santoianni R, Cohen C: Survivin expression in hepatocellular carcinoma: correlation with proliferation, prognostic parameters, and outcome. Mod Pathol 2004, 17:1378-1385.

80. Kannangai R, Wang J, Liu QZ, Sahin F, Torbenson M: Survivin overexpression in hepatocellular carcinoma is associated with p53 dysregulation. Int / Gastrointest Cancer 2005, 35:53-60.

81. Munn DH: Indoleamine 2,3-dioxygenase, tumor-induced tolerance and counter-regulation. Curr Opin Immunol 2006, 18:220-225

82. Larrea E, Riezu-Boj Jl, Gil-Guerrero L, Casares N, Aldabe R, Sarobe P, Civeira MP, Heeney JL, Rollier C, Verstrepen B, Wakita T, BorrásCuesta F, Lasarte JJ, Prieto J: Upregulation of indoleamine 2,3dioxygenase in hepatitis C virus infection. J Virol 2007, 8I:3662-3666

83. Dranoff G: Cytokines in cancer pathogenesis and cancer therapy. Nat Rev Cancer 2004, 4: I I-22.

84. Musiani P, Modesti A, Giovarelli M, Cavallo F, Colombo MP, Lollini PL, Forni G: Cytokines, tumour-cell death and immunogenicity: a question of choice. Immunol Today 1997, 18:32-36.

85. Humphreys RC, Halpern W: Trail receptors: targets for cancer therapy. Adv Exp Med Biol 2008, 6 1 5: I 27-I58.

86. Ahmed FY, Cassidy J: The treatment of advanced colorectal cancer with interferon-alpha: a review. Expert Opin Investig Drugs 1999, 8:13-18.

87. Kirkwood J: Cancer immunotherapy: the interferon-alpha experience. Semin Oncol 2002, 29:18-26.

88. Singh RK, Gutman M, Bucana CD, Sanchez R, Llansa N, Fidler IJ: Interferons alpha and beta down-regulate the expression of basic fibroblast growth factor in human carcinomas. Proc Natl Acad Sci USA 1995, 92:4562-4566.

89. Belardelli F, Ferrantini M, Proietti E, Kirkwood JM: Interferon-alpha in tumor immunity and immunotherapy. Cytokine Growth Factor Rev 2002, 13:119-134

90. Lai CL, Lau JY, Wu PC, Ngan H, Chung HT, Mitchell SJ, Corbett TJ, Chow AW, Lin H]: Recombinant interferon-alpha in inoperable hepatocellular carcinoma: a randomized controlled trial. Hepatology 1993, 17:389-394.

91. Llovet JM, Sala M, Castells L, Suarez Y, Vilana R, Bianchi L, Ayuso C, Vargas $V$, Rodes J, Bruix J: Randomized controlled trial of interferon treatment for advanced hepatocellular carcinoma. Hepatology 2000, 3 I:54-58.
92. Kubo S, Nishiguchi S, Hirohashi K, Tanaka H, Shuto T, Yamazaki O Shiomi S, Tamori A, Oka H, Igawa S, Kuroki T, Kinoshita H: Effects of long-term postoperative interferon-alpha therapy on intrahepatic recurrence after resection of hepatitis $C$ virusrelated hepatocellular carcinoma. A randomized, controlled trial. Ann Intern Med 200I, 134:963-967.

93. Ikeda K, Arase Y, Saitoh S, Kobayashi M, Suzuki Y, Suzuki F, Tsubota A, Chayama K, Murashima N, Kumada H: Interferon beta prevents recurrence of hepatocellular carcinoma after complete resection or ablation of the primary tumor-A prospective randomized study of hepatitis C virus-related liver cancer. Hepatology 2000, 32:228-232.

94. Shiratori Y, Shiina S, Teratani T, Imamura M, Obi S, Sato S, Koike Y, Yoshida $\mathrm{H}$, Omata M: Interferon therapy after tumor ablation improves prognosis in patients with hepatocellular carcinoma associated with hepatitis C virus. Ann Intern Med 2003, I38:299-306.

95. Patt YZ, Hassan MM, Lozano RD, Brown TD, Vauthey JN, Curley SA Ellis LM: Phase II trial of systemic continuous fluorouracil and subcutaneous recombinant interferon Alfa-2b for treatment of hepatocellular carcinoma. J Clin Oncol 2003, 21:421-427.

96. Sakon M, Nagano H, Dono K, Nakamori S, Umeshita K, Yamada A, Kawata S, Imai Y, lijima S, Monden M: Combined intraarterial 5 fluorouracil and subcutaneous interferon-alpha therapy for advanced hepatocellular carcinoma with tumor thrombi in the major portal branches. Cancer 2002, 94:435-442.

97. Grem JL, Jordan E, Robson ME, Binder RA, Hamilton JM, Steinberg SM, Arbuck SG, Beveridge RA, Kales AN, Miller JA, et al.: Phase II study of fluorouracil, leucovorin, and interferon alfa-2a in metastatic colorectal carcinoma. J Clin Oncol 1993, I I:I737-I745.

98. Hausmaninger $H$, Moser R, Samonigg $H$, Mlineritsch $B$, Schmidt $H$, Pecherstorfer M, Fridrik M, Kopf C, Nitsche D, Kaider A, Ludwig H: Biochemical modulation of 5 -fluorouracil by leucovorin with or without interferon-alpha-2c in patients with advanced colorectal cancer: final results of a randomised phase III study. Eur I Cancer 1999, 35:380-385.

99. Fountzilas G, Zisiadis A, Dafni U, Konstantaras C, Hatzitheoharis G, Papavramidis S, Bousoulegas A, Basdanis G, Giannoulis E, Dokmetzioglou J, et al.: Fluorouracil and leucovorin with or without interferon alfa-2a as adjuvant treatment, in patients with high-risk colon cancer: a randomized phase III study conducted by the Hellenic Cooperative Oncology Group. Oncology 2000, 58:227-236.

100. Palmieri G, Montella L, Milo M, Fiore R, Biondi E, Bianco AR, Martignetti $A$ : Ultra-low-dose interleukin-2 in unresectable hepatocellular carcinoma. Am J Clin Oncol 2002, 25:224-226.

10I. Aldeghi R, Lissoni P, Barni S, Ardizzoia A, Tancini G, Piperno A, Pozzi $M$, Ricci G, Conti A, Maestroni GJ: Low-dose interleukin-2 subcutaneous immunotherapy in association with the pineal hormone melatonin as a first-line therapy in locally advanced or metastatic hepatocellular carcinoma. Eur J Cancer 1994, 30A: $167-170$

102. Ishikawa T, Imawari M, Moriyama T, Ohnishi S, Matsuhashi N, Suzuki G, Takaku F: Immunotherapy of hepatocellular carcinoma with autologous lymphokine-activated killer cells and/or recombinant interleukin-2. J Cancer Res Clin Oncol 1988, I | 4:283-290.

103. Okuno K, Hirohata T, Nakamura K, Jinnai H, Shigeoka H, Koh K, Shindo K, Yasutomi M: Hepatic arterial infusions of interleukin2-based immunochemotherapy in the treatment of unresectable liver metastases from colorectal cancer. Clin Ther 1993, 15:672-683.

104. Lygidakis NJ, Savanis G, Pothoulakis J, Kapetanakis A: Transarterial locoregional immunostimulation and chemotherapy in patients with unresectable secondary liver tumours. Anticancer Res 1994, 14:643-646.

105. Correale P, Cusi MG, Tsang KY, Del Vecchio MT, Marsili S, Placa ML, Intrivici C, Aquino A, Micheli L, Nencini C, Ferrari F, Giorgi G, Bonmassar E, Francini G: Chemo-immunotherapy of metastatic colorectal carcinoma with gemcitabine plus FOLFOX 4 followed by subcutaneous granulocyte macrophage colonystimulating factor and interleukin-2 induces strong immunologic and antitumor activity in metastatic colon cancer patients. J Clin Oncol 2005, 23:8950-8958. 
106. Lygidakis NJ, Kosmidis P, Ziras N, Parissis J, Kyparidou E: Combined transarterial targeting locoregional immunotherapy-chemotherapy for patients with unresectable hepatocellular carcinoma: a new alternative for an old problem. J Interferon Cytokine Res 1995, I 5:467-472.

107. Reinisch W, Holub M, Katz A, Herneth A, Lichtenberger C, Schoniger-Hekele M, Waldhoer T, Oberhuber G, Ferenci P, Gangl A, Mueller C: Prospective pilot study of recombinant granulocytemacrophage colony-stimulating factor and interferongamma in patients with inoperable hepatocellular carcinoma. J Immunother 2002, 25:489-499.

108. Hieber U, Heim ME: Tumor necrosis factor for the treatment of malignancies. Oncology 1994, 5 I: I 142-153.

109. Merino D, Lalaoui N, Morizot A, Solary E, Micheau O: TRAIL in cancer therapy: present and future challenges. Expert Opin Ther Targets 2007, II:1299-1314.

1 10. Zhu Y, Chen L: Cancer therapeutic monoclonal antibodies targeting lymphocyte co-stimulatory pathways. Curr Opin Investig Drugs 2003, 4:691-695.

III. Greenwald RJ, Freeman GJ, Sharpe AH: The B7 family revisited. Annu Rev Immunol 2005, 23:5 I5-548.

I 12. Chen L, Ashe S, Brady WA, Hellstrom I, Hellstrom KE, Ledbetter JA, McGowan P, Linsley PS: Costimulation of antitumor immunity by the $B 7$ counterreceptor for the $T$ lymphocyte molecules CD28 and CTLA-4. Cell 1992, 7 I: I093-II02.

I 13. Riley JL, June CH: The CD28 family: a T-cell rheostat for therapeutic control of T-cell activation. Blood 2005, 105:|3-21.

I 14. Bertram EM, Dawicki W, Watts TH: Role of T cell costimulation in anti-viral immunity. Semin Immunol 2004, 16:185-196.

1 15. Suntharalingam G, Perry MR, Ward S, Brett SJ, Castello-Cortes A, Brunner MD, Panoskaltsis N: Cytokine storm in a phase I trial of the anti-CD28 monoclonal antibody TGNI4I2. N Engl J Med 2006, 355:1018-1028.

116. Myers LM, Vella AT: Interfacing T-cell effector and regulatory function through CD I 37 (4-IBB) co-stimulation. Trends Immunol 2005, 26:440-446.

1 17. Pollok KE, Kim Y], Zhou Z, Hurtado J, Kim KK, Pickard RT, Kwon BS: Inducible $T$ cell antigen 4-IBB. Analysis of expression and function. J Immunol 1993, 150:771-78I.

I 18. Melero I, Johnston JV, Shufford WW, Mittler RS, Chen L: NKI.I cells express 4-IBB (CDw I37) costimulatory molecule and are required for tumor immunity elicited by anti-4-IBB monoclonal antibodies. Cell Immunol 1998, 190:167-172.

119. Shuford WW, Klussman K, Tritchler DD, Loo DT, Chalupny J, Siadak AW, Brown T], Emswiler J, Raecho H, Larsen CP, Pearson TC, Ledbetter JA, Aruffo A, Mittler RS: 4- I BB costimulatory signals preferentially induce CD8+ $T$ cell proliferation and lead to the amplification in vivo of cytotoxic $\mathbf{T}$ cell responses. J Exp Med 1997, 186:47-55.

120. Takahashi C, Mittler RS, Vella AT: Cutting edge: 4-I BB is a bona fide CD8 T cell survival signal. J Immunol I999, I 62:5037-5040.

121. Melero I, Shuford WW, Newby SA, Aruffo A, Ledbetter JA, Hellstrom KE, Mittler RS, Chen L: Monoclonal antibodies against the 4-IBB T-cell activation molecule eradicate established tumors. Nat Med 1997, 3:682-685.

122. Mazzolini G, Murillo O, Atorrasagasti C, Dubrot J, Tirapu I, Rizzo M, Arina A, Alfaro C, Azpilicueta A, Berasain C, Perez-Gracia JL, Gonzalez A, Melero I: Immunotherapy and immunoescape in colorectal cancer. World J Gastroenterol 2007, I 3:5822-583 I.

123. Niu L, Strahotin S, Hewes B, Zhang B, Zhang Y, Archer D, Spencer T, Dillehay D, Kwon B, Chen L, Vella AT, Mittler RS: Cytokine-mediated disruption of lymphocyte trafficking, hemopoiesis, and induction of lymphopenia, anemia, and thrombocytopenia in anti-CD I 37-treated mice. J Immunol 2007, I 78:4 I 94-42 I3.

124. Croft M: Costimulation of T cells by OX40, 4-IBB, and CD27. Cytokine Growth Factor Rev 2003, 14:265-273.

125. Watts TH: TNF/TNFR family members in costimulation of $\mathbf{T}$ cell responses. Annu Rev Immunol 2005, 23:23-68.

126. Rogers PR, Song J, Gramaglia I, Killeen N, Croft M: OX40 promotes $\mathrm{Bcl}-\mathrm{xL}$ and $\mathrm{Bcl}-2$ expression and is essential for long-term survival of CD4 T cells. Immunity 200I, I5:445-455.

127. Weinberg AD, Rivera MM, Prell R, Morris A, Ramstad T, Vetto JT, Urba WJ, Alvord G, Bunce C, Shields J: Engagement of the OX-40 receptor in vivo enhances antitumor immunity. J Immunol 2000, 164:2160-2169.
128. Melero I, Hervas-Stubbs S, Glennie M, Pardoll DM, Chen L: Immunostimulatory monoclonal antibodies for cancer therapy. Nat Rev Cancer 2007, 7:95-106.

129. Teft WA, Kirchhof MG, Madrenas J: A molecular perspective of CTLA-4 function. Annu Rev Immunol 2006, 24:65-97.

130. Leach DR, Krummel MF, Allison JP: Enhancement of antitumor immunity by CTLA-4 blockade. Science 1996, 27I: I734-1736.

13I. Chambers CA, Kuhns MS, Egen JG, Allison JP: CTLA-4-mediated inhibition in regulation of $T$ cell responses: mechanisms and manipulation in tumor immunotherapy. Annu Rev Immunol 200I, 1 9:565-594.

132. Chen L: Co-inhibitory molecules of the B7-CD28 family in the control of T-cell immunity. Nat Rev Immunol 2004, 4:336-347.

133. Hirano F, Kaneko K, Tamura H, Dong H, Wang S, Ichikawa M, Rietz C, Flies DB, Lau JS, Zhu G, Tamada K, Chen L: Blockade of B7-H I and PD-I by monoclonal antibodies potentiates cancer therapeutic immunity. Cancer Res 2005, 65:1089-1096.

134. Xu J, Xu HY, Zhang Q, Song F, Jiang JL, Yang XM, Mi L, Wen N, Tian $R$, Wang L, Yao H, Feng Q, Zhang Y, Xing JL, Zhu P, Chen ZN: HAbI8G/CDI47 functions in invasion and metastasis of hepatocellular carcinoma. Mol Cancer Res 2007, 5:605-6I4.

135. Ku XM, Liao CG, Li Y, Yang XM, Yang B, Yao XY, Wang L, Kong LM, Zhao $P$, Chen ZN: Epitope mapping of series of monoclonal antibodies against the hepatocellular carcinoma-associated antigen HAb I 8G/CD I 47. Scand J Immunol 2007, 65:435-443.

136. Mokyr MB, Kalinichenko T, Gorelik L, Bluestone JA: Realization of the therapeutic potential of CTLA-4 blockade in low-dose chemotherapy-treated tumor-bearing mice. Cancer Res 1998, 58:530I-5304.

137. Demaria S, Kawashima N, Yang AM, Devitt ML, Babb JS, Allison JP, Formenti SC: Immune-mediated inhibition of metastases after treatment with local radiation and CTLA-4 blockade in a mouse model of breast cancer. Clin Cancer Res 2005, I I:728-734.

138. Miller AD: Human gene therapy comes of age. Nature 1992, 357:455-460.

139. Mulligan RC: The basic science of gene therapy. Science 1993, 260:926-932

140. Edelstein ML, Abedi MR, Wixon J, Edelstein RM: Gene therapy clinical trials worldwide 1989-2004-an overview. J Gene Med 2004, 6:597-602.

14I. Aiuti A, Bachoud-Lévi AC, Blesch A, Brenner MK, Cattaneo F, Chiocca EA, Gao G, High KA, Leen AM, Lemoine NR, McNeish IA, Meneguzzi G, Peschanski M, Roncarolo MG, Strayer DS, Tuszynski $\mathrm{MH}$, Waxman DJ, Wilson JM: Progress and prospects: gene therapy clinical trials (part 2). Gene Ther 2007, I 4:1555-1563.

142. Alexander BL, Ali RR, Alton EW, Bainbridge JW, Braun S, Cheng SH, Flotte TR, Gaspar HB, Grez M, Griesenbach U, Kaplitt MG, Ott MG, Seger R, Simons M, Thrasher AJ, Thrasher AZ, Ylä-Herttuala S: Progress and prospects: gene therapy clinical trials (part I). Gene Ther 2007, 14:1439-1447.

143. Cao L, Kulmburg P, Veelken H, Mackensen A, Mezes B, Lindemann A, Mertelsmann R, Rosenthal FM: Cytokine gene transfer in cancer therapy. Stem Cells 1998, I6(SuppI I):25I-260.

144. Qian C, Liu XY, Prieto J: Therapy of cancer by cytokines mediated by gene therapy approach. Cell Res 2006, 16:182-188.

145. Schmidt-Wolf GD, Schmidt-Wolf IG: Cytokines and gene therapy. Immunol Today 1995, 16:173-175.

146. Trinchieri G: Interleukin- 12 and the regulation of innate resistance and adaptive immunity. Nat Rev Immunol 2003, 3:133-146.

147. Colombo MP, Trinchieri G: Interleukin- 12 in anti-tumor immunity and immunotherapy. Cytokine Growth Factor Rev 2002, 13:155-168.

148. Angiolillo AL, Sgadari C, Taub DD, Liao F, Farber JM, Maheshwari S, Kleinman HK, Reaman GH, Tosato G: Human interferon-inducible protein 10 is a potent inhibitor of angiogenesis in vivo. $J$ Exp Med 1995, 182: I 55-162.

149. Mazzolini G, Narvaiza I, Bustos M, Duarte M, Tirapu I, Bilbao R, Qian C, Prieto J, Melero I: Alpha(v)beta(3) integrin-mediated adenoviral transfer of interleukin- 12 at the periphery of hepatic colon cancer metastases induces VCAM-I expression and T. cell recruitment. Mol Ther 200I, 3:665-672.

150. Leonard JP, Sherman ML, Fisher GL, Buchanan LJ, Larsen G, Atkins MB, Sosman JA, Dutcher JP, Vogelzang NJ, Ryan JL: Effects of singledose interleukin- 12 exposure on interleukin- 12 -associated toxicity and interferon-gamma production. Blood 1997, 90:2541-2548. 
15I. Mazzolini G, Prieto J, Melero I: Gene therapy of cancer with interleukin- I2. Curr Pharm Des 2003, 9:1981-|99|.

152. Adris S, Klein S, Jasnis M, Chuluyan E, Ledda M, Bravo A, Carbone C, Chernajovsky Y, Podhajcer O: IL- 10 expression by CT26 colon carcinoma cells inhibits their malignant phenotype and induces a $\mathrm{T}$ cell-mediated tumor rejection in the context of a systemic Th2 response. Gene Ther 1999, 6:1705-I7I2.

153. Mazzolini G, Qian C, Xie X, Sun Y, Lasarte JJ, Drozdzik M, Prieto J: Regression of colon cancer and induction of antitumor immunity by intratumoral injection of adenovirus expressing interleukin-12. Cancer Gene Ther 1999, 6:514-522.

154. Adris S, Chuluyan E, Bravo A, Berenstein M, Klein S, Jasnis M, Carbone $C$, Chernajovsky $Y$, Podhajcer OL: Mice vaccination with interleukin I2-transduced colon cancer cells potentiates rejection of syngeneic non-organ-related tumor cells. Cancer Res 2000, 60:6696-6703

155. Barajas M, Mazzolini G, Genove G, Bilbao R, Narvaiza I, Schmitz V, Sangro B, Melero I, Qian C, Prieto J: Gene therapy of orthotopic hepatocellular carcinoma in rats using adenovirus coding for interleukin I2. Hepatology 200I, 33:52-6I.

156. Barajas M, Mazzolini G, Genove G, Bilbao R, Narvaiza I, Schmitz V, Sangro B, Melero I, Qian C, Prieto J: Gene therapy of orthotopic hepatocellular carcinoma in rats using adenovirus coding for interleukin I2. Hepatology 200I, 33:52-6I.

I57. Mazzolini G, Qian C, Narvaiza I, Barajas M, Borras-Cuesta F, Xie X, Duarte $M$, Melero I, Prieto J: Adenoviral gene transfer of interleukin 12 into tumors synergizes with adoptive $\mathbf{T}$ cell therapy both at the induction and effector level. Hum Gene Ther 2000, I I:I I 3-125.

I58. Caruso M, Pham-Nguyen K, Kwong YL, Xu B, Kosai KI, Finegold M, Woo SL, Chen SH: Adenovirus-mediated interleukin- 12 gene therapy for metastatic colon carcinoma. Proc Natl Acad Sci USA 1996, 93:11302-11306.

159. Pützer BM, Stiewe T, Rödicker F, Schildgen $O$, Rühm S, Dirsch O, Fiedler M, Damen U, Tennant B, Scherer C, Graham FL, Roggendorf M: Large nontransplanted hepatocellular carcinoma in woodchucks: treatment with adenovirus-mediated delivery of interleukin I 2/B7.I genes. J Natl Cancer Inst 200I, 93:472-479.

160. Mazzolini G, Narvaiza I, Perez-Diez A, Rodriguez-Calvillo M, Qian C, Sangro B, Ruiz J, Prieto J, Melero I: Genetic heterogeneity in the toxicity to systemic adenoviral gene transfer of interleukinI 2. Gene Ther 200I, 8:259-267.

16I. Narvaiza I, Mazzolini G, Barajas M, Duarte M, Zaratiegui M, Qian C, Melero I, Prieto J: Intratumoral coinjection of two adenoviruses, one encoding the chemokine IFN-gamma-inducible protein- 10 and another encoding IL- I2, results in marked antitumoral synergy. J Immunol 2000, I 64:3 II2-3I 22.

162. Mazzolini G, Narvaiza I, Martinez-Cruz LA, Arina A, Barajas M, Galofre JC, Qian C, Mato JM, Prieto J, Melero I: Pancreatic cancer escape variants that evade immunogene therapy through loss of sensitivity to IFNgamma-induced apoptosis. Gene Ther 2003, 10:1067-1078.

163. Sangro B, Mazzolini G, Ruiz J, Herraiz M, Quiroga J, Herrero I, Benito A, Larrache J, Pueyo J, Subtil JC, Olagüe C, Sola J, Sádaba B, Lacasa C, Melero I, Qian C, Prieto J: Phase I trial of intratumoral injection of an adenovirus encoding interleukin- $I 2$ for advanced digestive tumors. J Clin Oncol 2004, 22: I389-I397.

164. Clerici M, Shearer GM, Clerici E: Cytokine dysregulation in invasive cervical carcinoma and other human neoplasias: time to consider the THI/TH2 paradigm. J Natl Cancer Inst 1998, 90:261-263.

165. Lopez MV, Adris SK, Bravo Al, Chernajovsky Y, Podhajcer OL: IL-I 2 and IL- 10 expression synergize to induce the immune-mediated eradication of established colon and mammary tumors and lung metastasis. J Immunol 2005, I 75:5885-5894

166. Gilly FN, Beaujard A, Bienvenu J, Trillet Lenoir V, Glehen O, Thouvenot D, Malcus C. Favrot M, Dumontet C, Lombard-Bohas C, Garbit F, Gueugniaud PY, Vignal J, Aymard M, Touraine Moulin F, Roos M, Pavirani A, Courtney M: Gene therapy with Adv-IL-2 in unresectable digestive cancer: phase I-II study, intermediate report. Hepatogastroenterology I999, 46(SuppI I): I 268- I 273.

167. Rubin J, Galanis E, Pitot HC, Richardson RL, Burch PA, Charboneau JW, Reading CC, Lewis BD, Stahl S, Akporiaye ET, Harris DT: Phase I study of immunotherapy of hepatic metastases of colorectal carcinoma by direct gene transfer of an allogeneic histocompatibility antigen, HLA-B7. Gene Ther 1997, 4:419-425.
168. Sun Y, Peng D, Lecanda J, Schmitz V, Barajas M, Qian C, Prieto J: In vivo gene transfer of CD40 ligand into colon cancer cells induces local production of cytokines and chemokines, tumor eradication and protective antitumor immunity. Gene Ther 2000, 7:|467-|476.

169. Schmitz V, Barajas M, Wang L, Peng D, Duarte M, Prieto J, Qian C: Adenovirus-mediated CD40 ligand gene therapy in a rat model of orthotopic hepatocellular carcinoma. Hepatology 200I, 34:72-8I.

170. Liu TC, Kirn D: Gene therapy progress and prospects cancer: oncolytic viruses. Gene Ther 2008, I 5( I 2):877-884.

17I. Malhotra S, Kim T, Zager J, Bennett J, Ebright M, D'Angelica M, Fong $Y$ : Use of an oncolytic virus secreting GM-CSF as combined oncolytic and immunotherapy for treatment of colorectal and hepatic adenocarcinomas. Surgery 2007, I 41:520-529.

172. Bischoff JR, Kirn DH, Williams A, Heise C, Horn S, Muna M, Ng L, Nye JA, Sampson-Johannes A, Fattaey A, McCormick F: An adenovirus mutant that replicates selectively in p53-deficient human tumor cells. Science 1996, 274:373-376.

173. Habib N, Salama H, Abd El Latif Abu Median A, Isac Anis I, Abd Al Aziz RA, Sarraf C, Mitry R, Havlik R, Seth P, Hartwigsen J, Bhushan R, Nicholls J, Jensen S: Clinical trial of EIB-deleted adenovirus (dII520) gene therapy for hepatocellular carcinoma. Cancer Gene Ther 2002, 9:254-259.

174. Hamid O, Varterasian ML, Wadler S, Hecht JR, Benson A 3rd, Galanis E, Uprichard M, Omer C, Bycott P, Hackman RC, Shields AF: Phase II trial of intravenous $\mathrm{Cl}-\mathrm{IO42}$ in patients with metastatic colorectal cancer. J Clin Oncol 2003, 2 I: | 498-I 504.

175. Hernandez-Alcoceba R, Sangro B, Prieto J: Gene therapy of liver cancer. Ann Hepatol 2007, 6:5-14.

176. Banchereau J, Steinman RM: Dendritic cells and the control of immunity. Nature 1998, 392:245-252.

177. Reis e Sousa C: Dendritic cells in a mature age. Nat Rev Immunol 2006, 6:476-483.

178. Aoudjehane L, Pissaia A Jr, Scatton O, Podevin P, Massault PP, Chouzenoux S, Soubrane O, Calmus Y, Conti F: Interleukin-4 induces the activation and collagen production of cultured human intrahepatic fibroblasts via the STAT-6 pathway. Lab Invest 2008, 88:973-985.

179. Sriram U, Biswas C, Behrens EM, Dinnall JA, Shivers DK, Monestier M, Argon Y, Gallucci S: IL-4 suppresses dendritic cell response to type I interferons. J Immunol 2007, I 79:6446-6455.

180. Nestle FO, Farkas A, Conrad C: Dendritic-cell-based therapeutic vaccination against cancer. Curr Opin Immunol 2005, 17:163-169.

18I. Melcher A, Todryk S, Bateman A, Chong H, Lemoine NR, Vile RG: Adoptive transfer of immature dendritic cells with autologous or allogeneic tumor cells generates systemic antitumor immunity. Cancer Res 1999, 59:2802-2805

182. Nishioka Y, Hirao M, Robbins PD, Lotze MT, Tahara $\mathrm{H}$ : Induction of systemic and therapeutic antitumor immunity using intratumoral injection of dendritic cells genetically modified to express interleukin 12. Cancer Res 1999, 59:4035-404I.

183. Melero I, Duarte M, Ruiz J, Sangro B, Galofre J, Mazzolini G, Bustos $M$, Qian $C$, Prieto J: Intratumoral injection of bone-marrow derived dendritic cells engineered to produce interleukin- I 2 induces complete regression of established murine transplantable colon adenocarcinomas. Gene Ther 1999, 6: $1779-1784$.

184. Chi KH, Liu SJ, Li CP, Kuo HP, Wang YS, Chao Y, Hsieh SL: Combination of conformal radiotherapy and intratumoral injection of adoptive dendritic cell immunotherapy in refractory hepatoma. J Immunother 2005, 28: I29-135.

185. Miller PW, Sharma S, Stolina M, Butterfield LH, Luo J, Lin Y, Dohadwala M, Batra RK, Wu L, Economou JS, Dubinett SM: Intratumoral administration of adenoviral interleukin 7 gene-modified dendritic cells augments specific antitumor immunity and achieves tumor eradication. Hum Gene Ther 2000, I I:53-65.

186. Vera M, Razquin N, Prieto J, Melero I, Fortes P, Gonzalez-Aseguinolaza G: Intratumoral injection of dendritic cells transduced by an SV40-based vector expressing interleukin-I5 induces curative immunity mediated by CD8+ T lymphocytes and NK cells. Mol Ther 2005, I 2:950-959.

187. Mazzolini G, Alfaro C, Sangro B, Feijoó E, Ruiz J, Benito A, Tirapu I, Arina A, Sola J, Herraiz M, Lucena F, Olagüe C, Subtil J, Quiroga J, Herrero I, Sádaba B, Bendandi M, Qian C, Prieto J, Melero I: Intratu- 
moral injection of dendritic cells engineered to secrete interleukin- 12 by recombinant adenovirus in patients with metastatic gastrointestinal carcinomas. J Clin Oncol 2005, 23:999-1010.

188. Feijoó E, Alfaro C, Mazzolini G, Serra P, Peñuelas I, Arina A, Huarte E, Tirapu I, Palencia B, Murillo O, Ruiz J, Sangro B, Richter JA, Prieto J, Melero I: Dendritic cells delivered inside human carcinomas are sequestered by interleukin-8. Int J Cancer 2005, I 16:275-28I.

189. Grewal IS, Flavell RA: CD40 and CDI54 in cell-mediated immunity. Annu Rev Immunol 1998, 16: I I I-I35.

190. Kikuchi T, Miyazawa N, Moore MA, Crystal RG: Tumor regression induced by intratumor administration of adenovirus vector expressing CD40 ligand and naive dendritic cells. Cancer Res 2000, 60:639I-6395.

191. Kikuchi T, Moore MA, Crystal RG: Dendritic cells modified to express CD40 ligand elicit therapeutic immunity against preexisting murine tumors. Blood 2000, 96:91-99.

192. Chu XY, Chen LB, Zang J, Wang JH, Zhang Q, Geng HC: Effect of bone marrow-derived monocytes transfected with RNA of mouse colon carcinoma on specific antitumor immunity. World J Gastroenterol 2005, I I:760-763.

193. Saha A, Chatterjee SK, Foon KA, Primus FJ, Sreedharan S, Mohanty K, Bhattacharya-Chatterjee M: Dendritic cells pulsed with an antiidiotype antibody mimicking carcinoembryonic antigen (CEA) can reverse immunological tolerance to CEA and induce antitumor immunity in CEA transgenic mice. Cancer Res 2004, 64:4995-5003.

194. Morse MA, Deng Y, Coleman D, Hull S, Kitrell-Fisher E, Nair S, Schlom J, Ryback ME, Lyerly HK: A Phase I study of active immunotherapy with carcinoembryonic antigen peptide (CAP-I)pulsed, autologous human cultured dendritic cells in patients with metastatic malignancies expressing carcinoembryonic antigen. Clin Cancer Res 1999, 5:1331-1338.

195. Fong L, Hou Y, Rivas A, Benike C, Yuen A, Fisher GA, Davis MM, Engleman EG: Altered peptide ligand vaccination with FIt3 ligand expanded dendritic cells for tumor immunotherapy. Proc Natl Acad Sci USA 200I, 98:8809-88I4.

196. Stift A, Friedl J, Dubsky P, Bachleitner-Hofmann T, Schueller G Zontsich T, Benkoe T, Radelbauer K, Brostjan C, Jakesz R, Gnant M: Dendritic cell-based vaccination in solid cancer. J Clin Oncol 2003, $21: 135-142$

197. Iwashita Y, Tahara K, Goto S, Sasaki A, Kai S, Seike M, Chen CL, Kawano K, Kitano S: A phase I study of autologous dendritic cell-based immunotherapy for patients with unresectable primary liver cancer. Cancer Immunol Immunother 2003, 52:155-161.

198. Tamir A, Basagila E, Kagahzian A, Jiao L, Jensen S, Nicholls J, Tate $P$, Stamp G, Farzaneh F, Harrison P, Stauss H, George AJ, Habib N, Lechler RI, Lombardi G: Induction of tumor-specific T-cell responses by vaccination with tumor lysate-loaded dendritic cells in colorectal cancer patients with carcinoembryonicantigen positive tumors. Cancer Immunol Immunother 2007, 56:2003-2016.

199. Morse MA, Deng Y, Coleman D, Hull S, Kitrell-Fisher E, Nair S, Schlom J, Ryback ME, Lyerly HK: A Phase I study of active immunotherapy with carcinoembryonic antigen peptide (CAP-I)pulsed, autologous human cultured dendritic cells in patients with metastatic malignancies expressing carcinoembryonic antigen. Clin Cancer Res 1999, 5: I33 I-1338.

200. Itoh T, Ueda Y, Kawashima I, Nukaya I, Fujiwara H, Fuji N, Yamashita T, Yoshimura T, Okugawa K, Iwasaki T, Ideno M, Takesako K, Mitsuhashi M, Orita K, Yamagishi H: Immunotherapy of solid cancer using dendritic cells pulsed with the HLA-A24-restricted peptide of carcinoembryonic antigen. Cancer Immunol Immunother 2002, 5 I:99-106.

20I. Ueda $Y$, Itoh T, Nukaya I, Kawashima I, Okugawa K, Yano $Y$, Yamamoto Y, Naitoh K, Shimizu K, Imura K, Fuji N, Fujiwara H, Ochiai T, Itoi H, Sonoyama T, Hagiwara A, Takesako K, Yamagishi H: Dendritic cell-based immunotherapy of cancer with carcinoembryonic antigen-derived, HLA-A24-restricted CTL epitope: Clinical outcomes of 18 patients with metastatic gastrointestinal or lung adenocarcinomas. Int ] Oncol 2004, 24:909-917.

202. Babatz J, Rollig C, Lobel B, Folprecht G, Haack M, Gunther H, Kohne $\mathrm{CH}$, Ehninger G, Schmitz M, Bornhauser M: Induction of cellular immune responses against carcinoembryonic antigen in patients with metastatic tumors after vaccination with altered peptide ligand-loaded dendritic cells. Cancer Immunol Immunother 2006, 55:268-276.

203. Kalinski $P$, Mailliard RB, Giermasz A, Zeh HJ, Basse P, Bartlett DL, Kirkwood JM, Lotze MT, Herberman RB: Natural killer-dendritic cell cross-talk in cancer immunotherapy. Expert Opin Biol Ther 2005, 5:1303-1315

204. Rodriguez-Calvillo M, Duarte M, Tirapu I, Berraondo P, Mazzolini G Qian C, Prieto J, Melero I: Upregulation of natural killer cells functions underlies the efficacy of intratumorally injected dendritic cells engineered to produce interleukin-12. Exp Hematol 2002, 30:195-204.

205. Osada T, Clay T, Hobeika A, Lyerly HK, Morse MA: NK cell activation by dendritic cell vaccine: a mechanism of action for clinical activity. Cancer Immunol Immunother 2006, 55: I I22-I I 3I.

206. Furumoto K, Soares L, Engleman EG, Merad M: Induction of potent antitumor immunity by in situ targeting of intratumoral DCs. J Clin Invest 2004, I I 3:774-783.

207. Morse M, Langer L, Starodub A, Hobeika A, Clay T, Lyerly HK: Current immunotherapeutic strategies in colon cancer. Surg Oncol Clin N Am 2007, 16:873-900.

208. von Mehren M: Colorectal cancer vaccines: what we know and what we don't yet know. Semin Oncol 2005, 32:76-84.

209. Prieto J, Qian C, Sangro B, Melero I, Mazzolini G: Biologic therapy of liver tumors. Surg Clin North Am 2004, 84:673-696.

210. Chiriva-Internati M, Grizzi F, Wachtel MS, Jenkins M, Ferrari R, Cobos $E$, Frezza EE: Biological treatment for liver tumor and new potential biomarkers. Dig Dis Sci 2008, 53:836-843.

21I. Elkord E, Hawkins RE, Stern PL: Immunotherapy for gastrointestinal cancer: current status and strategies for improving efficacy. Expert Opin Biol Ther 2008, 8:385-395.

212. Ho WY, Yee C, Greenberg PD: Adoptive therapy with CD8(+) T cells: it may get by with a little help from its friends. I Clin Invest 2002, II 0: 1415-1417.

213. Rosenberg SA, Restifo NP, Yang JC, Morgan RA, Dudley ME: Adoptive cell transfer: a clinical path to effective cancer immunotherapy. Nat Rev Cancer 2008, 8:299-308.

214. June $\mathrm{CH}$ : Principles of adoptive T cell cancer therapy. J Clin Invest 2007, I I7:1204-1212.

215. Pang YL, Zhang HG, Peng JR, Pang XW, Yu S, Xing Q, Yu X, Gong L, Yin $Y H$, Zhang $Y$, Chen WF: The immunosuppressive tumor microenvironment in hepatocellular carcinoma. Cancer Immunol Immunother 2008.

216. Dong XY, Peng JR, Ye YJ, Chen HS, Zhang LJ, Pang XW, Li Y, Zhang $Y$, Wang S, Fant ME, Yin YH, Chen WF: Placl is a tumor-specific antigen capable of eliciting spontaneous antibody responses in human cancer patients. Int / Cancer 2008, I 22:2038-2043.

217. Grimm CF, Ortmann D, Mohr L, Michalak S, Krohne TU, Meckel S, Eisele S, Encke J, Blum HE, Geissler M: Mouse alpha-fetoproteinspecific DNA-based immunotherapy of hepatocellular carcinoma leads to tumor regression in mice. Gastroenterology 2000 , 1 19:1104-1112

218. Vollmer CM Jr, Eilber FC, Butterfield LH, Ribas A, Dissette VB, Koh A, Montejo LD, Lee MC, Andrews KJ, McBride WH, Glaspy JA, Economou JS: Alpha-fetoprotein-specific genetic immunotherapy for hepatocellular carcinoma. Cancer Res 1999, 59:3064-3067.

219. Chen CH, Chen G], Lee HS, Huang GT, Yang PM, Tsai LJ, Chen DS, Sheu JC: Expressions of cancer-testis antigens in human hepatocellular carcinomas. Cancer Lett 200I, 164:189-195.

220. Kobayashi Y, Higashi T, Nouso K, Nakatsukasa H, Ishizaki M, Kaneyoshi T, Toshikuni N, Kariyama K, Nakayama E, Tsuji T: Expression of MAGE, GAGE and BAGE genes in human liver diseases: utility as molecular markers for hepatocellular carcinoma. Hepatol 2000, 32:6I2-6I7.

22I. Yamashita N, Ishibashi H, Hayashida K, Kudo J, Takenaka K, Itoh K, Niho $Y$ : High frequency of the MAGE-I gene expression in hepatocellular carcinoma. Hepatology 1996, 24: | $437-\mid 440$

222. Jeng YM, Peng SY, Lin CY, Hsu HC: Overexpression and amplification of Aurora-A in hepatocellular carcinoma. Clin Cancer Res 2004, 10:2065-207I.

223. Giannelli G, Marinosci F, Sgarra C, Lupo L, Dentico P, Antonaci S Clinical role of tissue and serum levels of SCCA antigen in hepatocellular carcinoma. Int J Cancer 2005, I I 6:579-583.

224. Nakatsura T, Komori $H$, Kubo T, Yoshitake $Y$, Senju S, Katagiri $T$, Furukawa Y, Ogawa M, Nakamura Y, Nishimura Y: Mouse homo- 
logue of a novel human oncofetal antigen, glypican-3, evokes T-cell-mediated tumor rejection without autoimmune reactions in mice. Clin Cancer Res 2004, 10:8630-8640.

225. Liu FF, Dong XY, Pang XW, Xing Q, Wang HC, Zhang HG, Li Y, Yin YH, Fant M, Ye YJ, Shen DH, Zhang Y, Wang S, Chen WF: The specific immune response to tumor antigen CPI and its correlation with improved survival in colon cancer patients. Gastroenterology 2008, 134:998-1006.

226. Lee IN, Chen CH, Sheu JC, Lee HS, Huang GT, Yu CY, Lu FJ, Chow LP: Identification of human hepatocellular carcinoma-related biomarkers by two-dimensional difference gel electrophoresis and mass spectrometry. I Proteome Res 2005, 4:2062-2069.

227. Evdokimova VN, Butterfield LH: Alpha-fetoprotein and other tumour-associated antigens for immunotherapy of hepatocellular cancer. Expert Opin Biol Ther 2008, 8:325-336.

228. Bracci L, Moschella F, Sestili P, La Sorsa V, Valentini M, Canini I, Baccarini S, Maccari S, Ramoni C, Belardelli F, Proietti E: Cyclophosphamide enhances the antitumor efficacy of adoptively transferred immune cells through the induction of cytokine expression, B-cell and T-cell homeostatic proliferation, and specific tumor infiltration. Clin Cancer Res 2007, 1 3:644-653.

229. Lotze MT, Line BR, Mathisen DJ, Rosenberg SA: The in vivo distribution of autologous human and murine lymphoid cells grown in T cell growth factor (TCGF): implications for the adoptive immunotherapy of tumors. J Immunol 1980, I 25:|487-|493.

230. Rosenberg SA, Lotze MT, Muul LM, Chang AE, Avis FP, Leitman S, Linehan WM, Robertson CN, Lee RE, Rubin JT, et al.: A progress report on the treatment of 157 patients with advanced cancer using lymphokine-activated killer cells and interleukin-2 or high-dose interleukin-2 alone. N Engl J Med 1987, 3 16:889-897.

23I. Osband ME, Lavin PT, Babayan RK, Graham S, Lamm DL, Parker B, Sawczuk I, Ross S, Krane RJ: Effect of autolymphocyte therapy on survival and quality of life in patients with metastatic renal-cell carcinoma. Lancet 1990, 335:994-998.

232. Onishi S, Saibara T, Fujikawa M, Sakaeda H, Matsuura $Y$, Matsunaga $Y$, Yamamoto $Y$ : Adoptive immunotherapy with lymphokineactivated killer cells plus recombinant interleukin 2 in patients with unresectable hepatocellular carcinoma. Hepatology 1989, 10:349-353.

233. Takayama T, Makuuchi M, Sekine $T$, Terui S, Shiraiwa $H$, Kosuge $T$, Yamazaki S, Hasegawa H, Suzuki K, Yamagata M, et al.: Distribution and therapeutic effect of intraarterially transferred tumorinfiltrating lymphocytes in hepatic malignancies. A preliminary report. Cancer 1991, 68:2391-2396.

234. Takayama T, Sekine T, Makuuchi M, Yamasaki S, Kosuge T, Yamamoto J, Shimada K, Sakamoto M, Hirohashi S, Ohashi Y, Kakizoe T: Adoptive immunotherapy to lower postsurgical recurrence rates of hepatocellular carcinoma: a randomised trial. Lancet 2000 , 356:802-807.

235. Nakamori M, Iwahashi M, Nakamura M, Ueda K, Zhang X, Yamaue H: Intensification of antitumor effect by $T$ helper I-dominant adoptive immunogene therapy for advanced orthotopic colon cancer. Clin Cancer Res 2003, 9:2357-2365.

236. Curiel TJ: Tregs and rethinking cancer immunotherapy. J Clin Invest 2007, I I7: I 167-1 I74.

237. Rico M, Matar P, Zacarías Fluck M, Giordano R, Scharovsky O: Low dose Cyclophosphmide (Cy) treatment induces a decrease in the percentage of regulatory $\mathrm{T}$ cells in lymphoma-bearing rats. Proc Am Assoc Cancer Res 2007, 48:233.

238. Cheever MA, Greenberg PD, Fefer A, Gillis S: Augmentation of the anti-tumor therapeutic efficacy of long-term cultured $T$ lymphocytes by in vivo administration of purified interleukin 2. J Exp Med 1982, 155:968-980.

239. Ganss R, Ryschich E, Klar E, Arnold B, Hammerling GJ: Combination of T-cell therapy and trigger of inflammation induces remodeling of the vasculature and tumor eradication. Cancer Res 2002, 62:1462-1470.

240. Chakraborty M, Abrams SI, Camphausen K, Liu K, Scott T, Coleman $\mathrm{CN}$, Hodge JW: Irradiation of tumor cells up-regulates Fas and enhances CTL lytic activity and CTL adoptive immunotherapy. J Immunol 2003, 170:6338-6347.

24I. Quezada SA, Peggs KS, Curran MA, Allison JP: CTLA4 blockade and GM-CSF combination immunotherapy alters the intra- tumor balance of effector and regulatory $\mathbf{T}$ cells. I Clin Invest 2006, I16:1935-1945.

\section{Publish with Bio Med Central and every scientist can read your work free of charge}

"BioMed Central will be the most significant development for disseminating the results of biomedical research in our lifetime. "

Sir Paul Nurse, Cancer Research UK

Your research papers will be:

- available free of charge to the entire biomedical community

- peer reviewed and published immediately upon acceptance

- cited in PubMed and archived on PubMed Central

- yours - you keep the copyright 